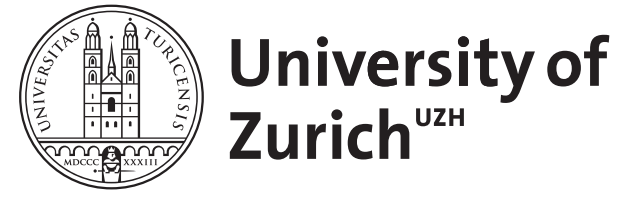

\title{
Das Kastilische und der alfonsinische Hof: über Texttraditionen, Sprache
} und Geschichte

\author{
Kabatek, Johannes
}

Posted at the Zurich Open Repository and Archive, University of Zurich

ZORA URL: https://doi.org/10.5167/uzh-86205

Book Section

Originally published at:

Kabatek, Johannes (2008). Das Kastilische und der alfonsinische Hof: über Texttraditionen, Sprache und Geschichte. In: Grebner, Gundula; Fried, Johannes. Kulturtransfer und Hofgesellschaft im Mittelalter. Wissenskultur am sizilianischen und kastilischen Hof im 13. Jahrhundert. Berlin: Akademie-Verlag, $351-366$ 


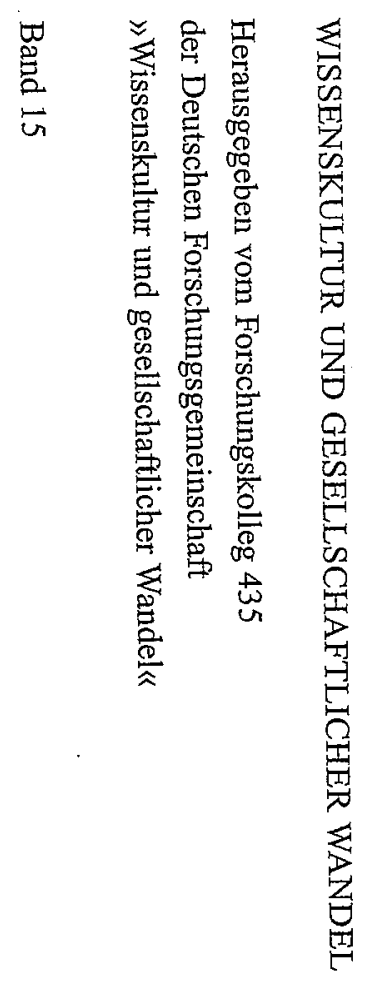

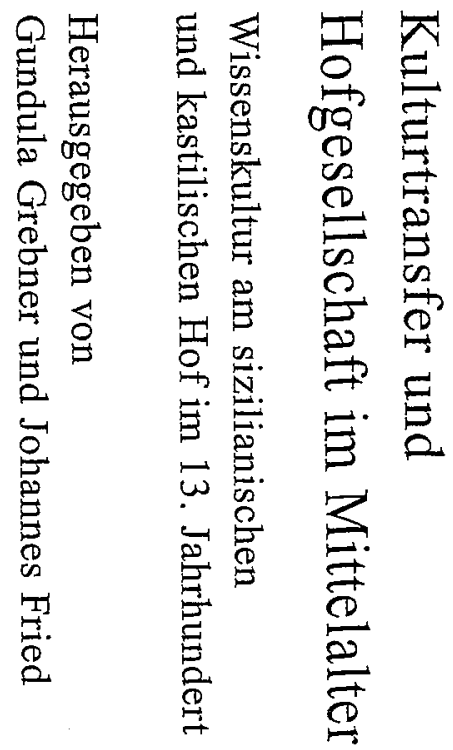



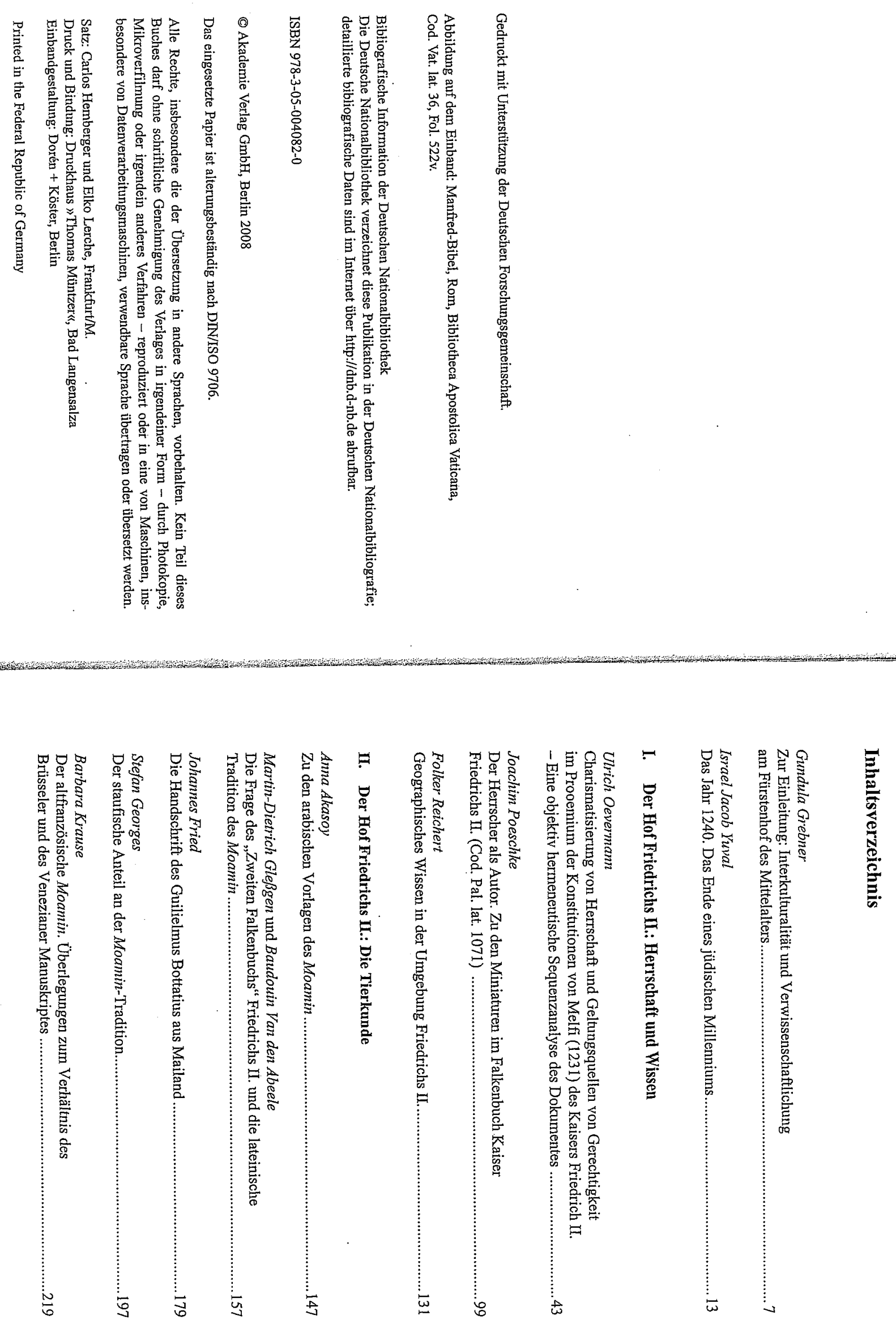


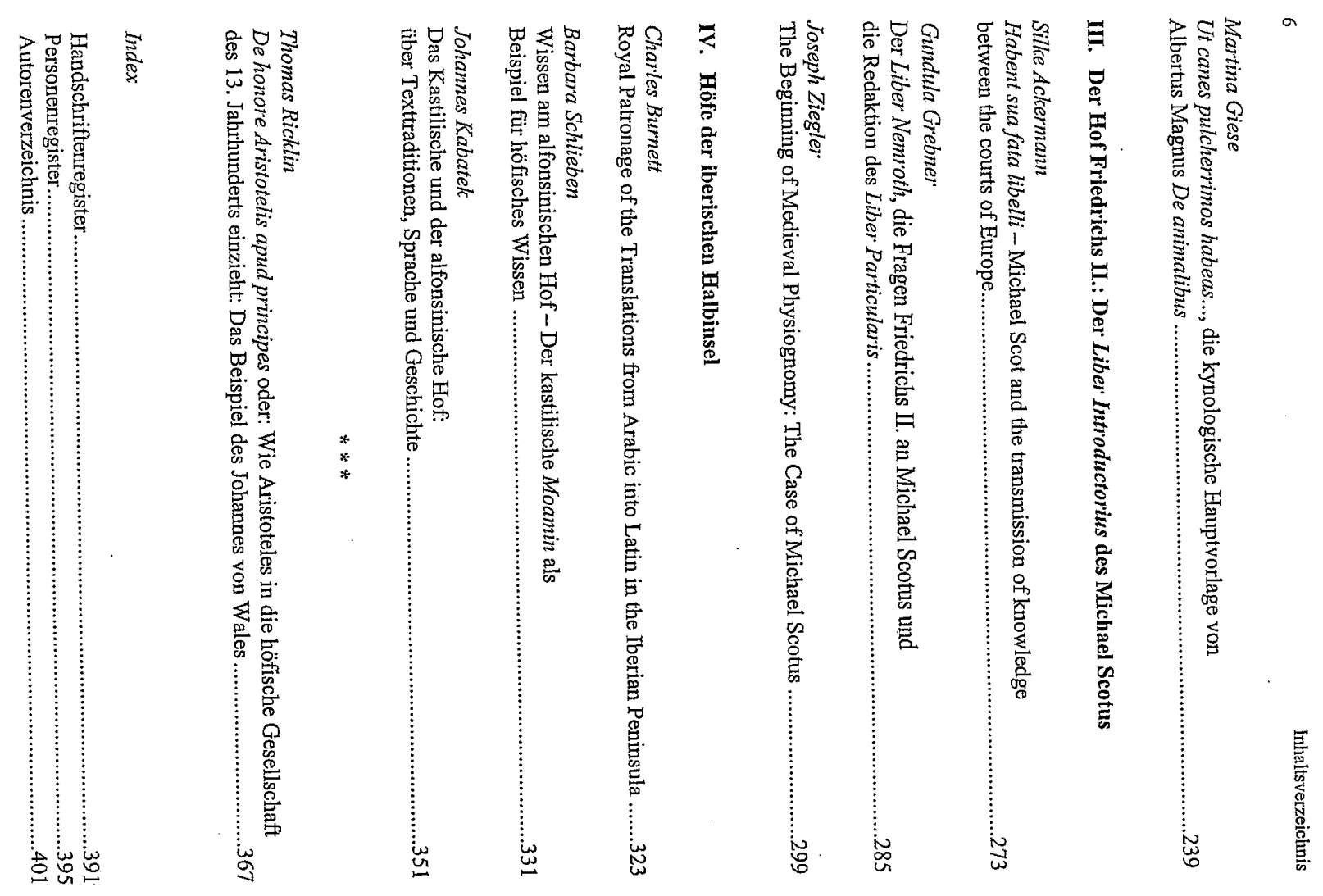

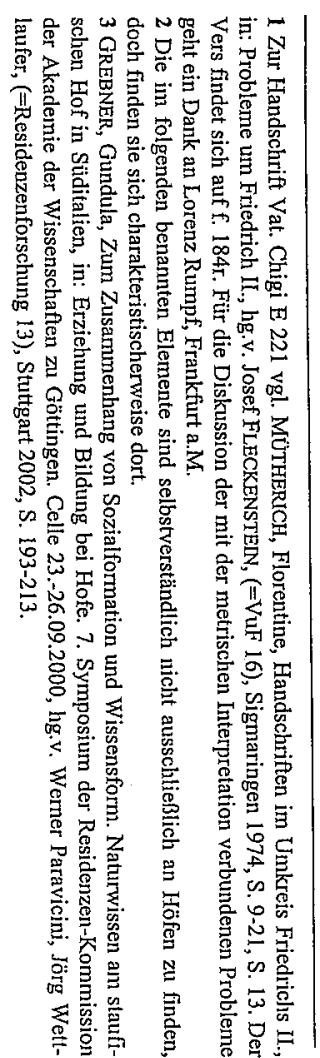

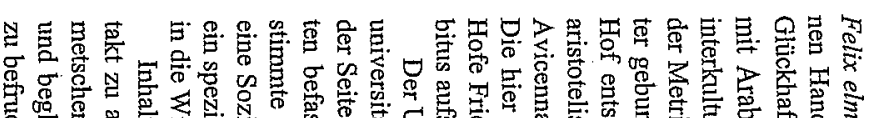

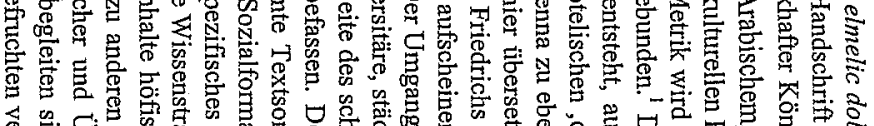

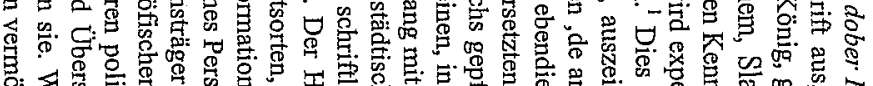

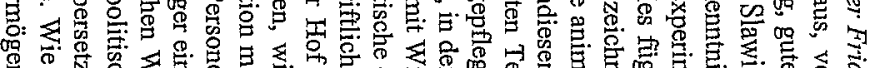

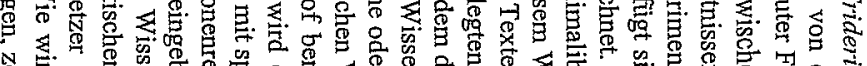
숭.

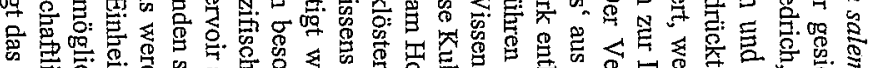

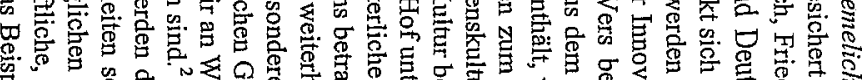

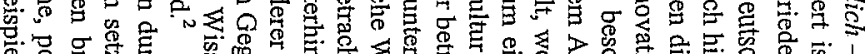

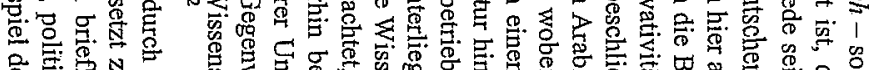

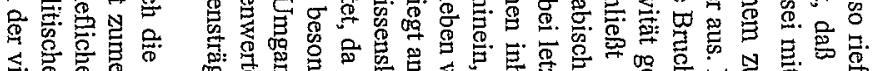

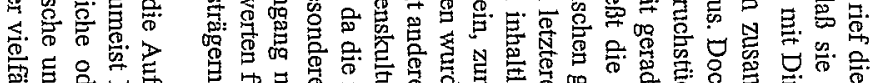

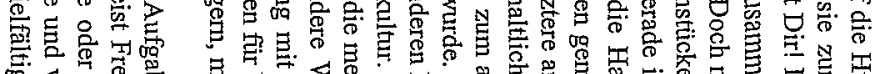

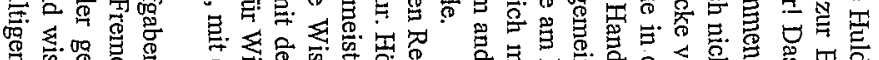

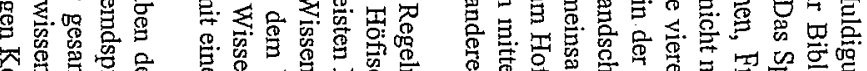

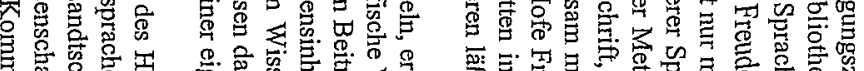

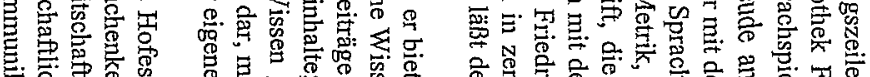

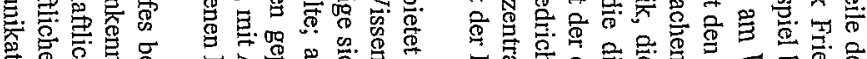

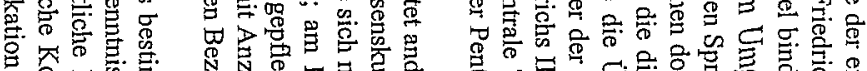

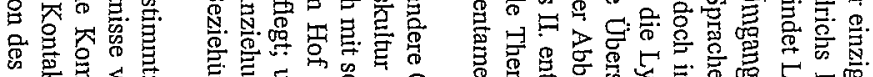

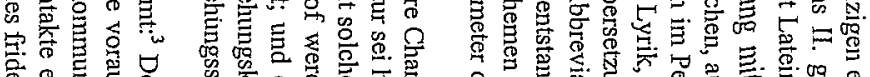

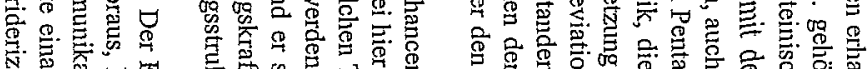

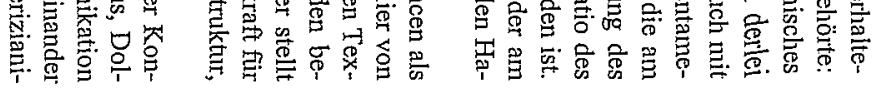

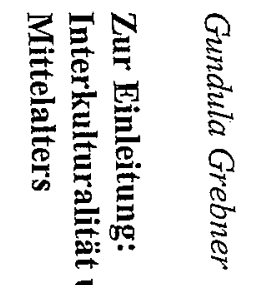

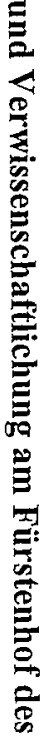




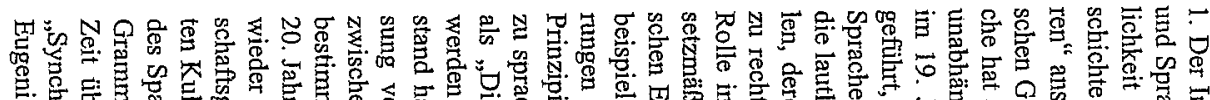

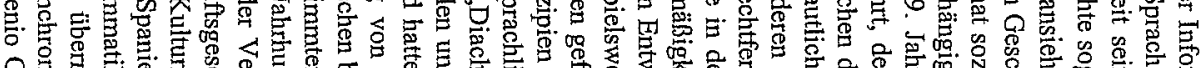

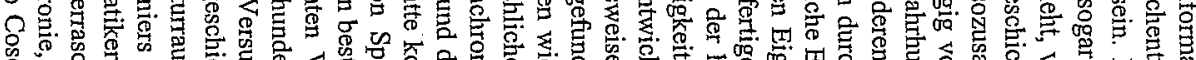

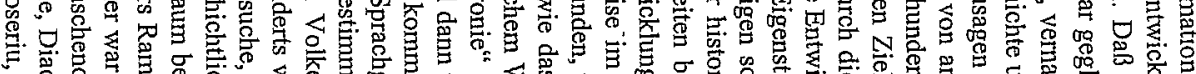

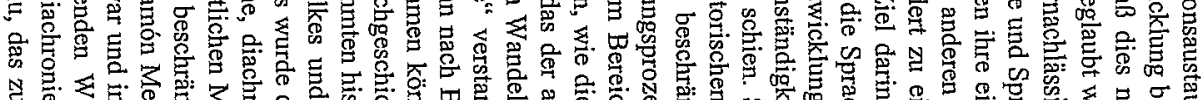

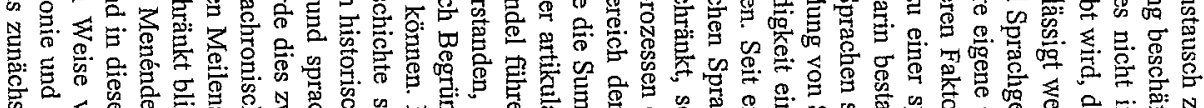

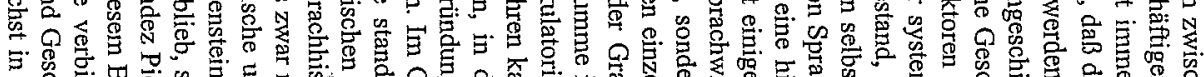

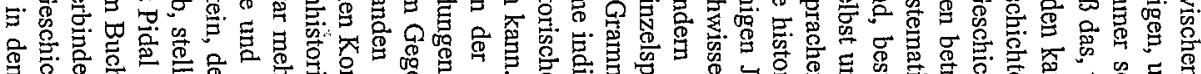

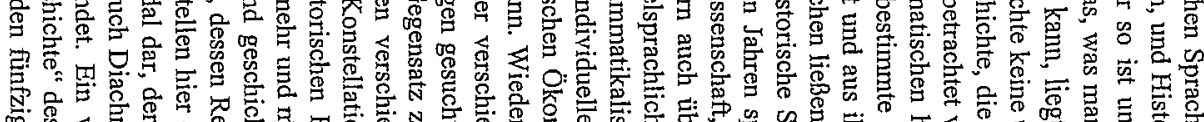

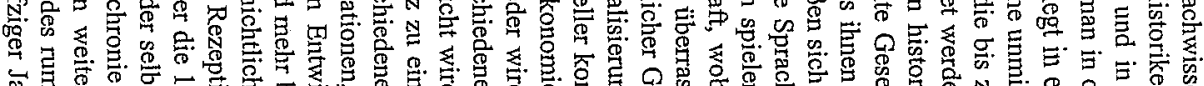

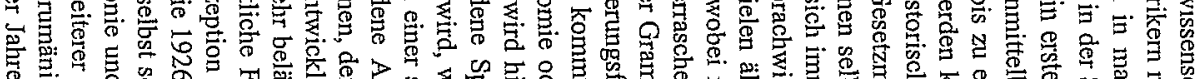

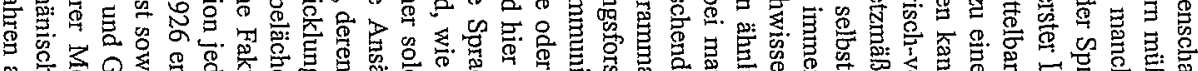

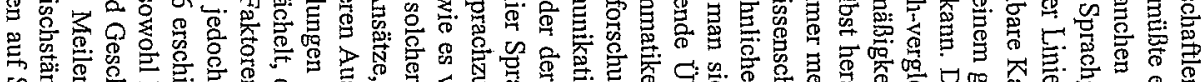

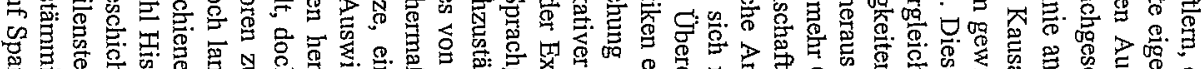

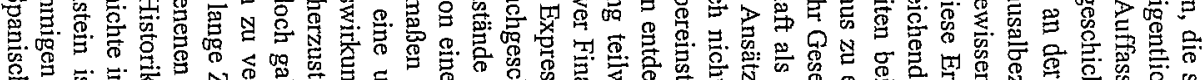

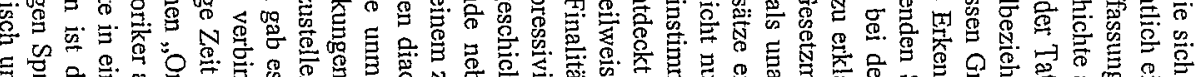

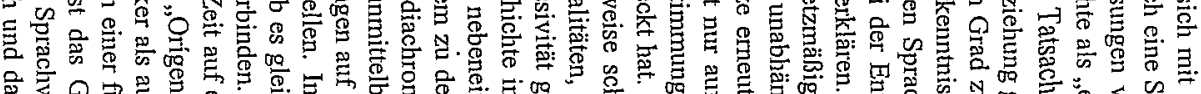

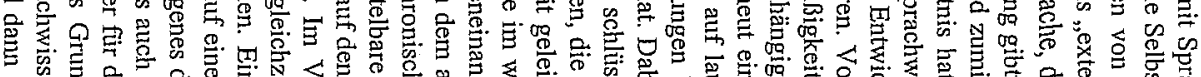

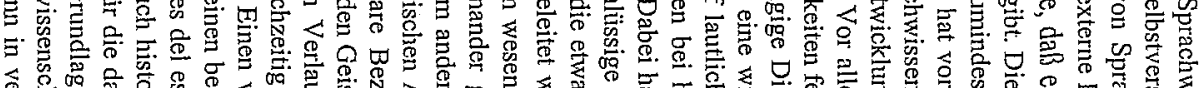

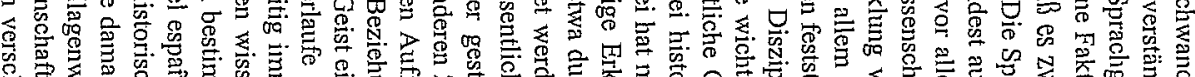

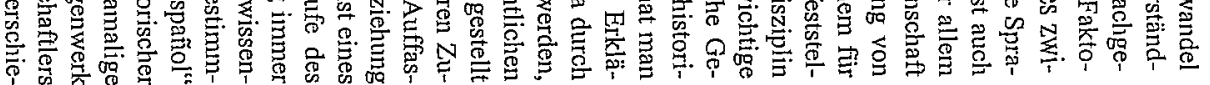

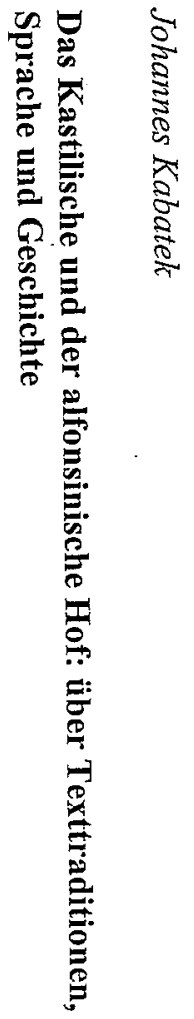




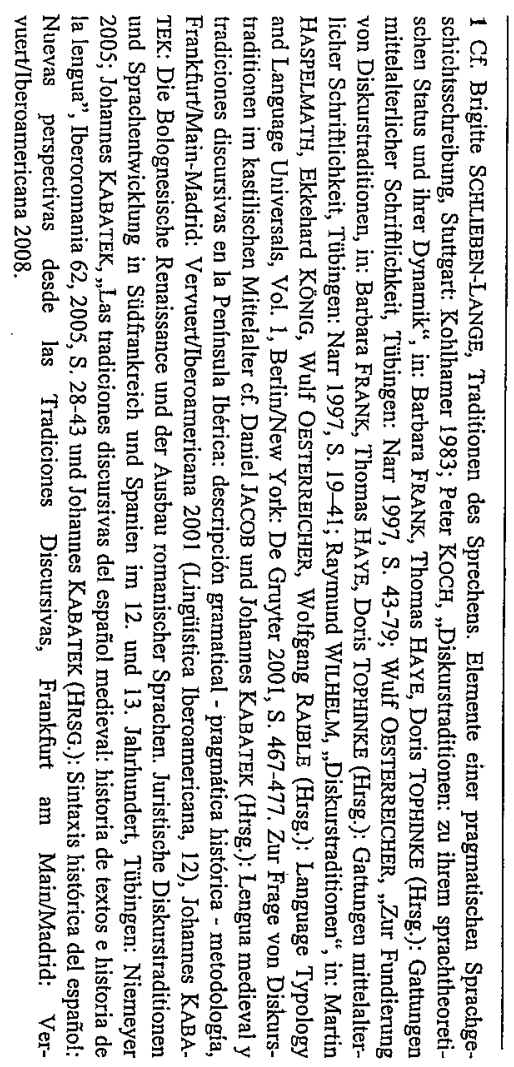

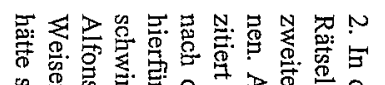

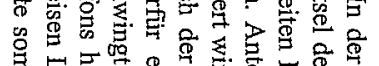

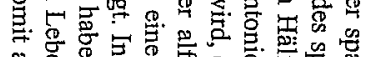

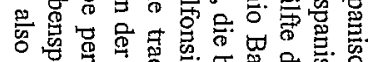

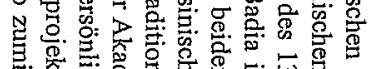

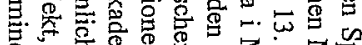

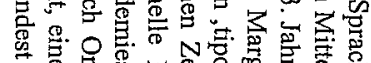

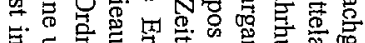

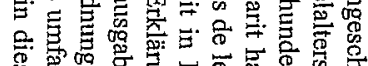

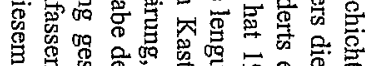

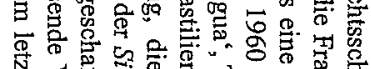

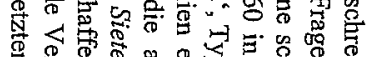
웅

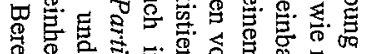

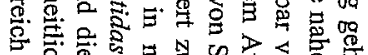

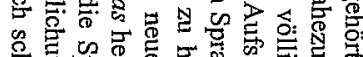

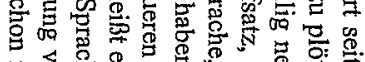

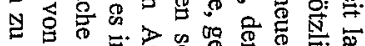

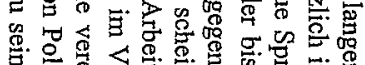

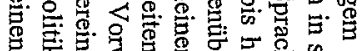
可.

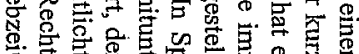

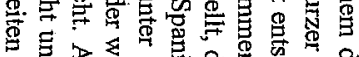

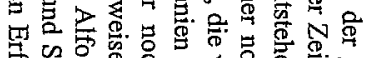

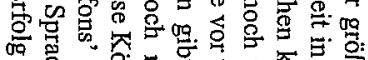

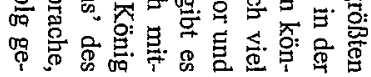

E.

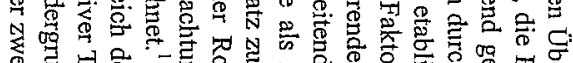

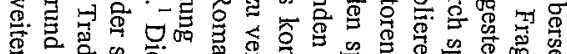

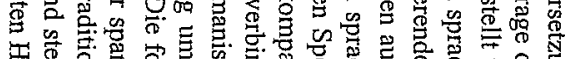

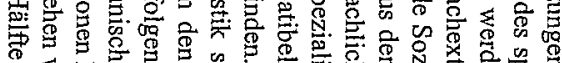

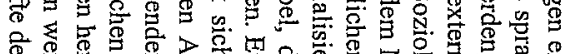
क

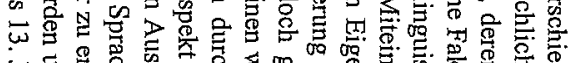

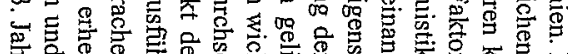

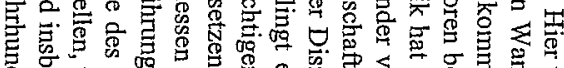

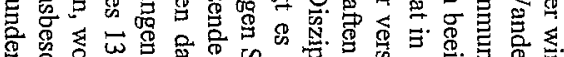

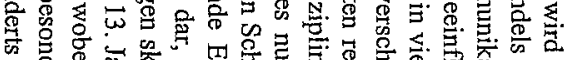

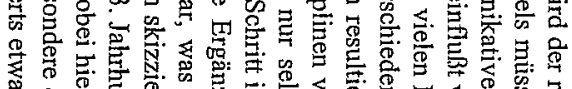
क्ष

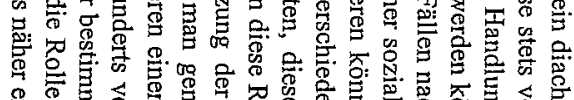

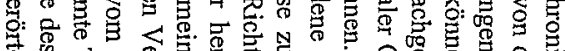

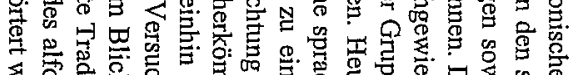

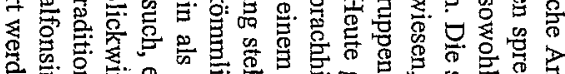

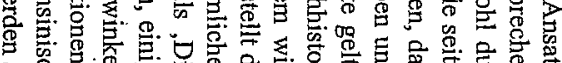

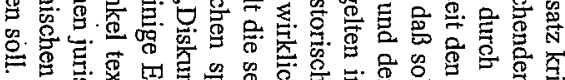

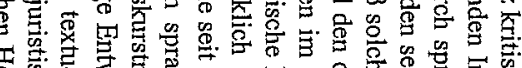

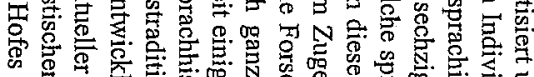

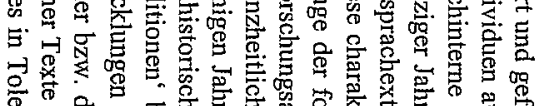

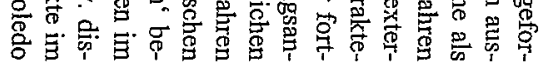

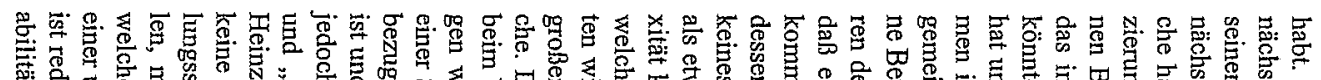

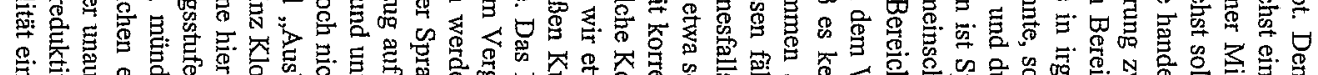

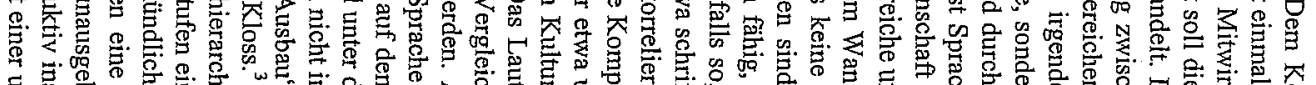

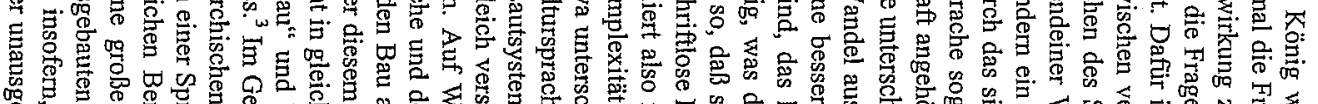

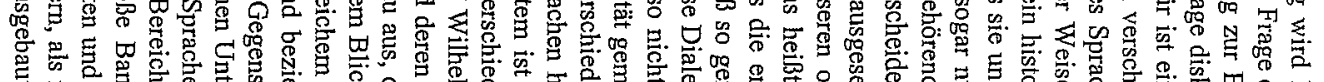

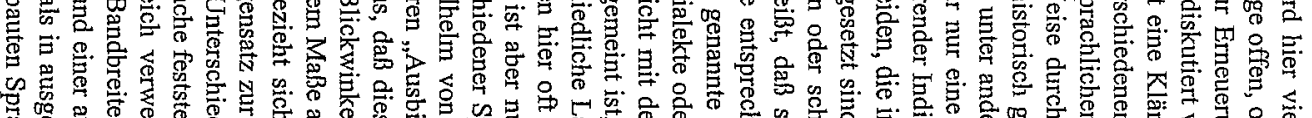

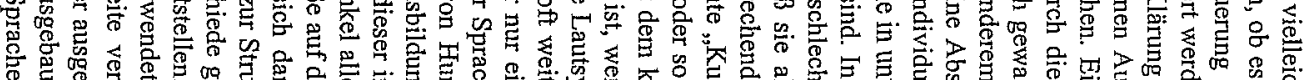

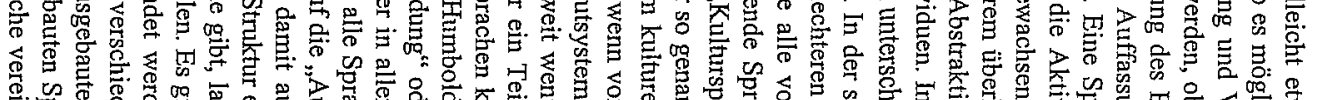

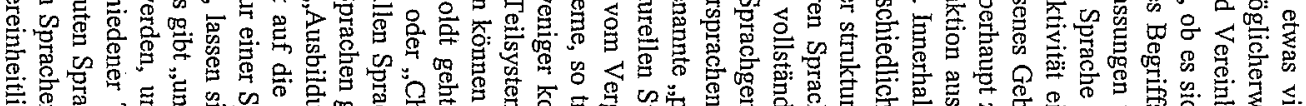

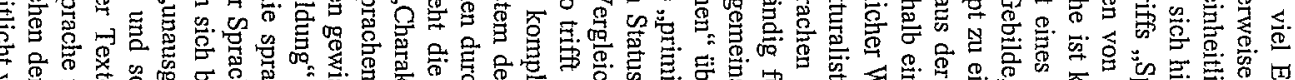

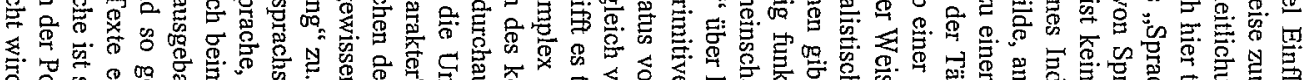

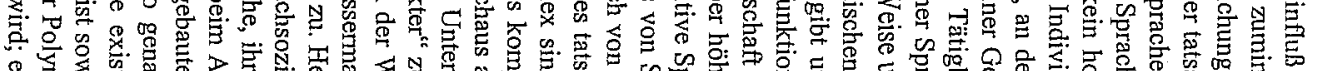

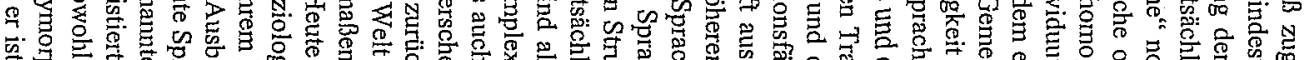

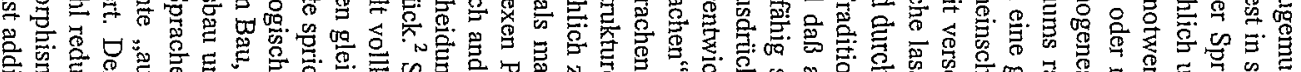

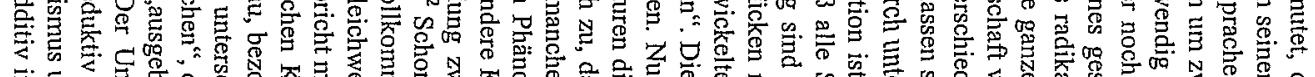

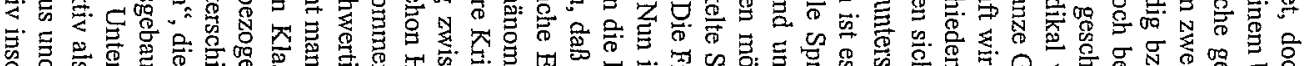

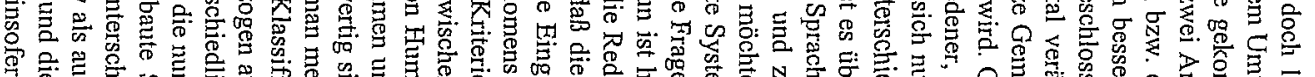

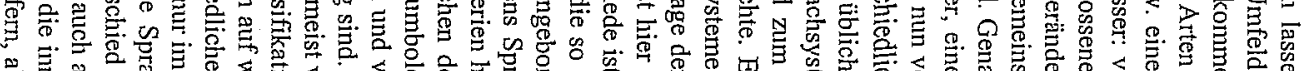

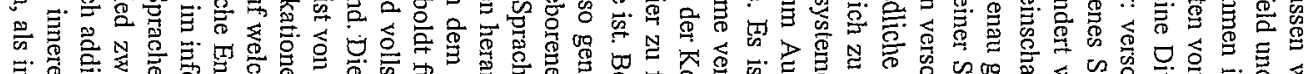

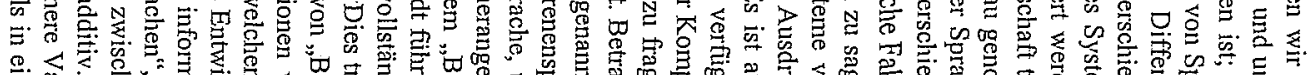

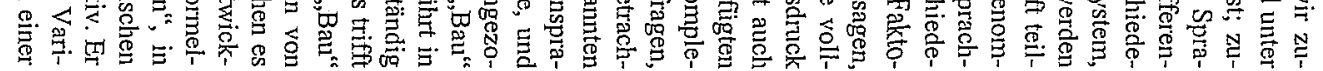




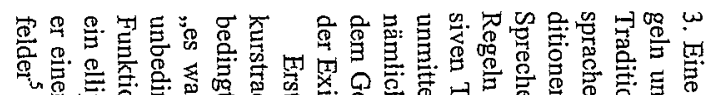

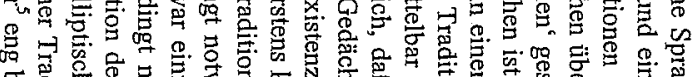

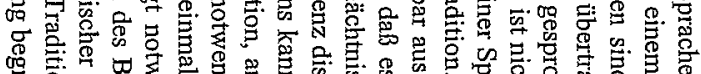

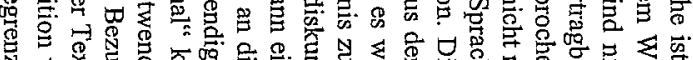

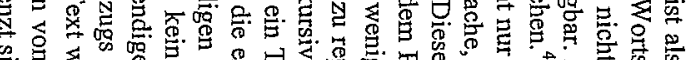

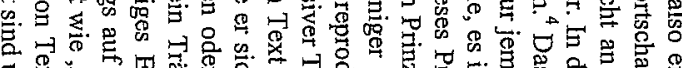

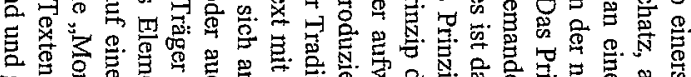

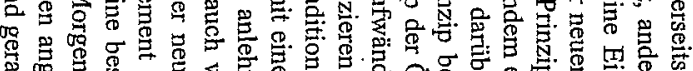

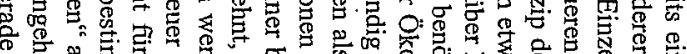

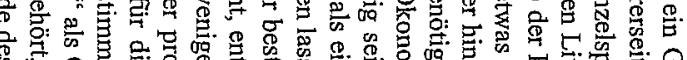

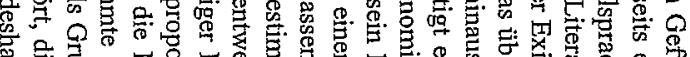

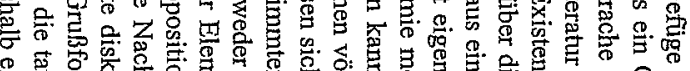

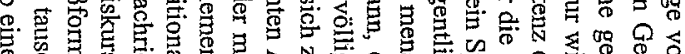

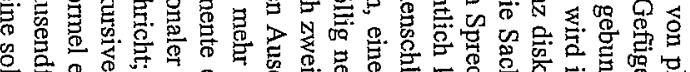

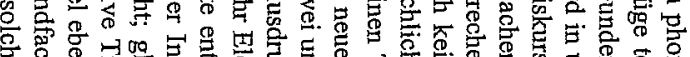

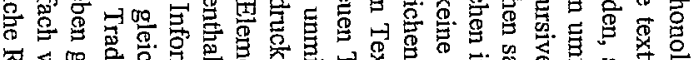

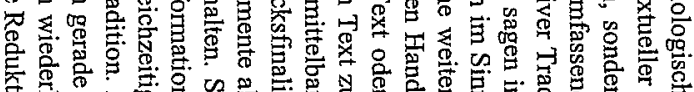

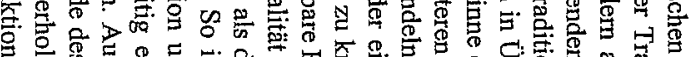

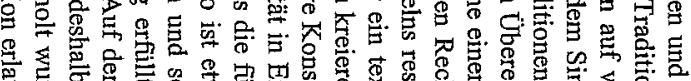

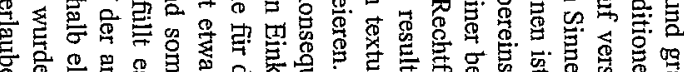

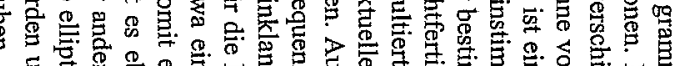

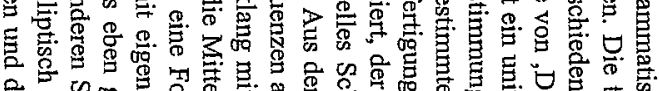

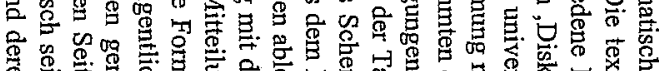

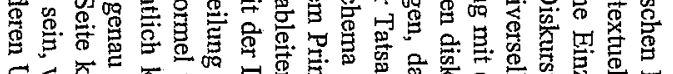

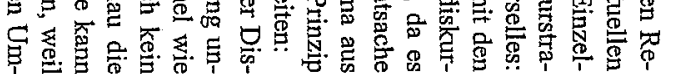

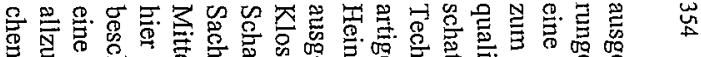

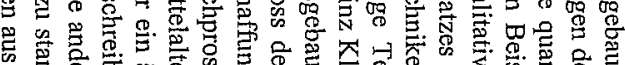

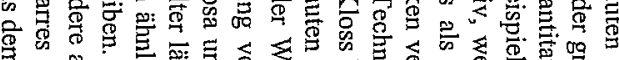

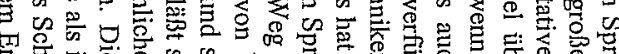

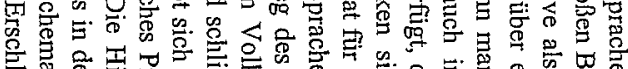

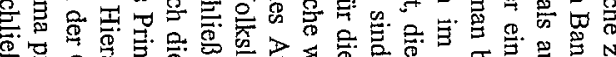

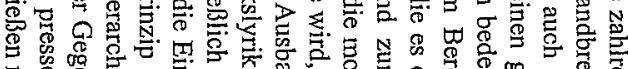

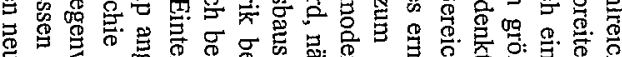

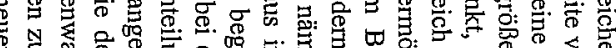

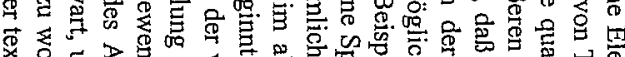

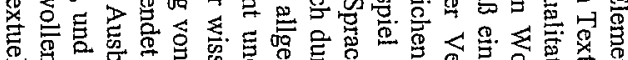
要

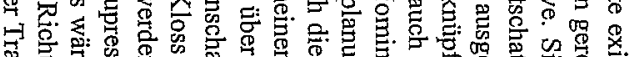

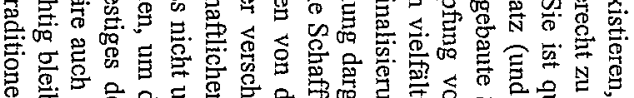

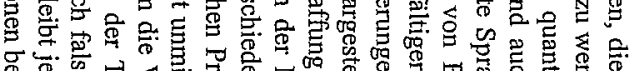

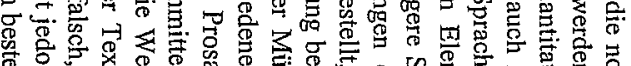

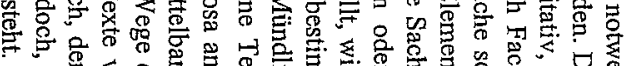

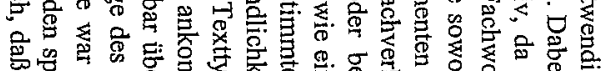

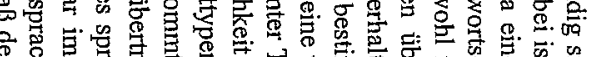
政

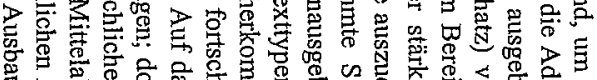

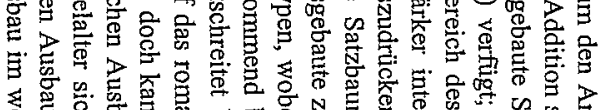

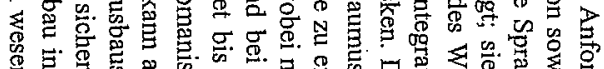

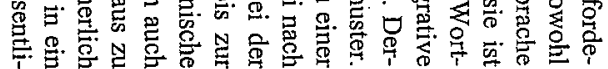

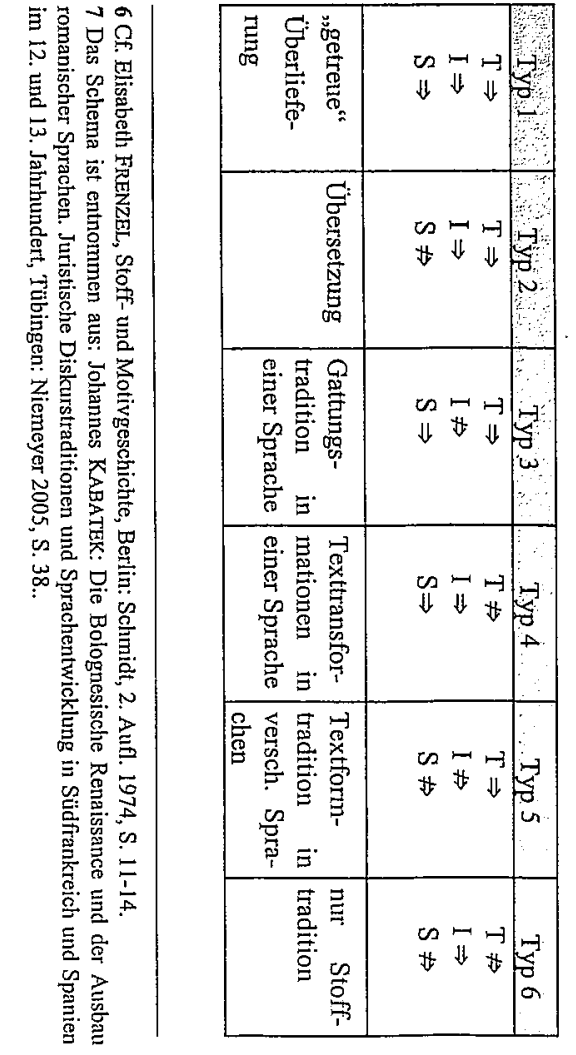

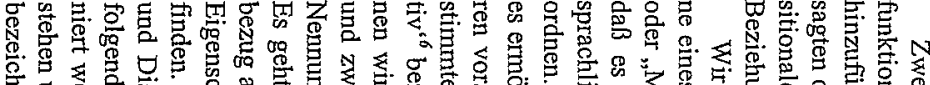

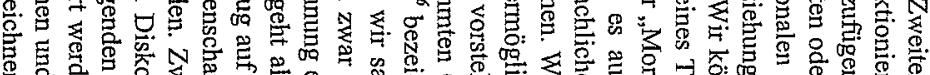

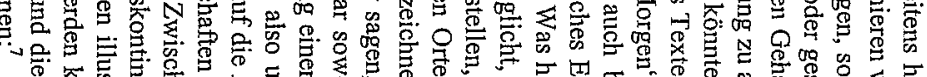

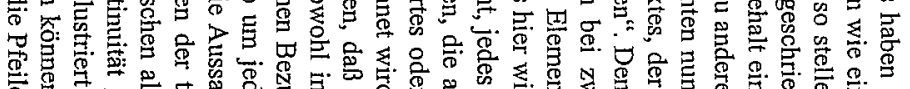

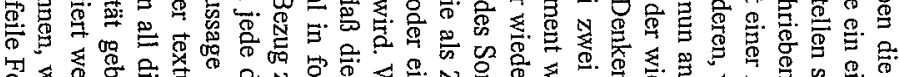

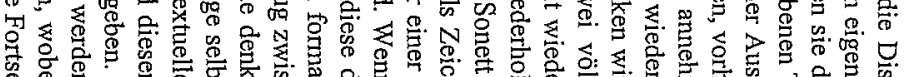

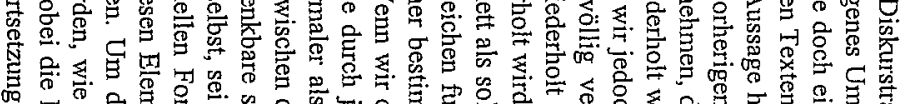

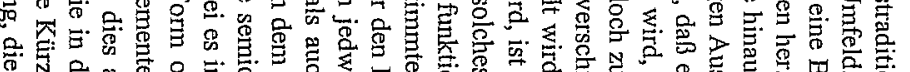

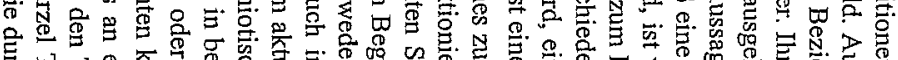

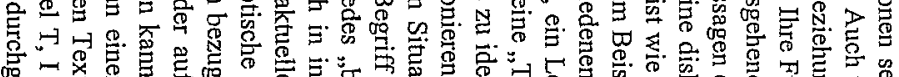

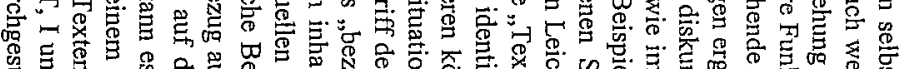

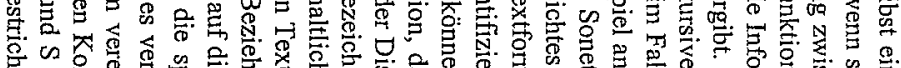

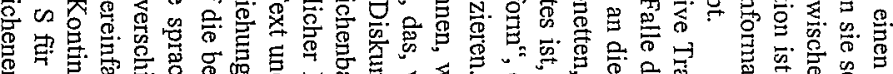

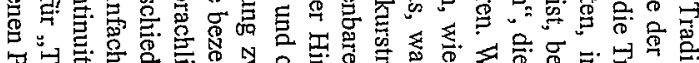

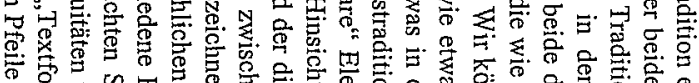

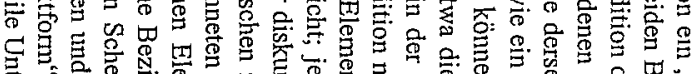

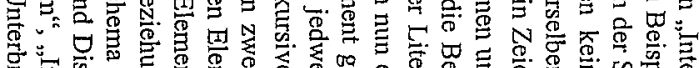

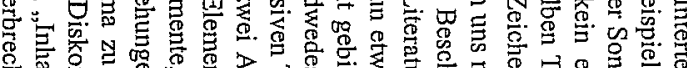

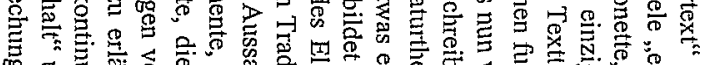

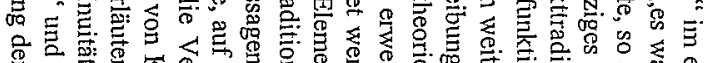

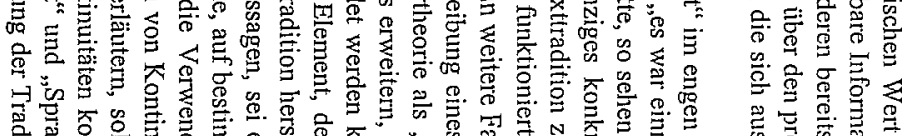

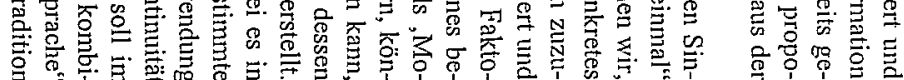




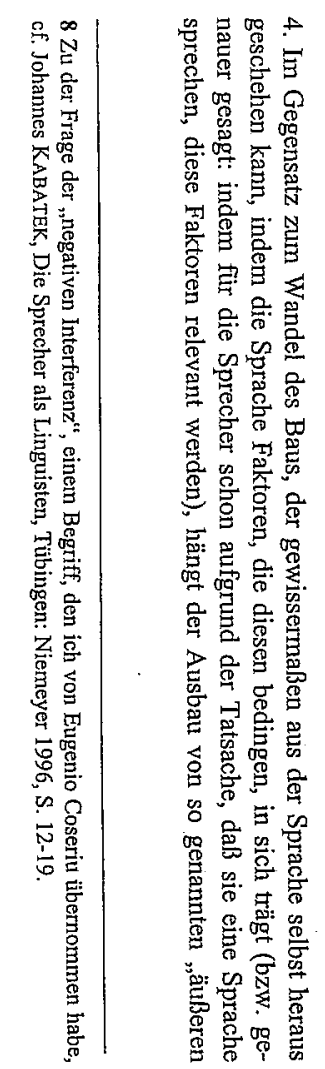

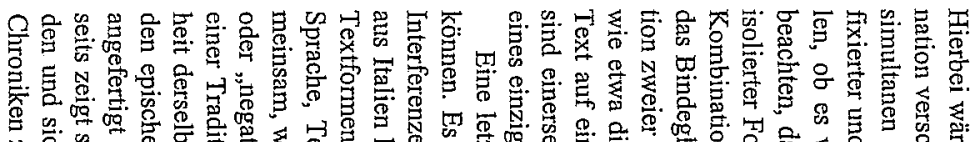

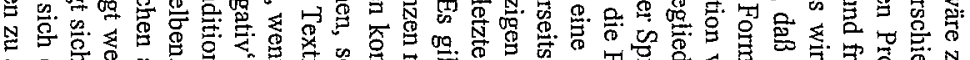

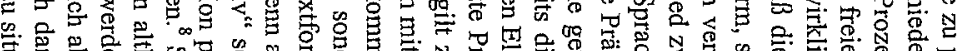

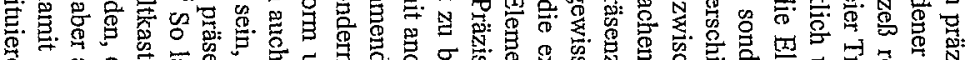

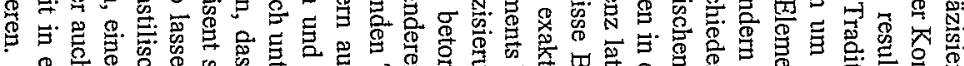

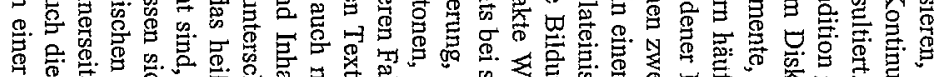

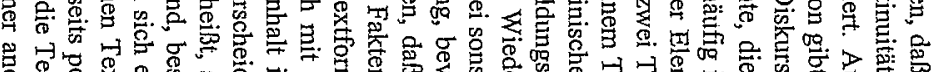

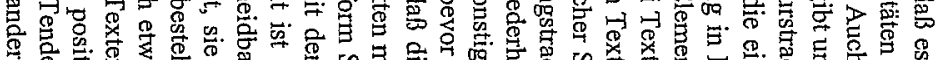

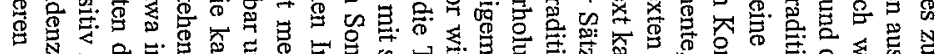

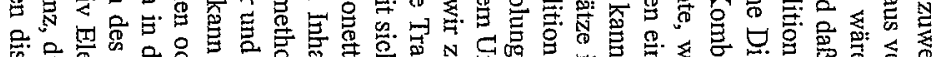

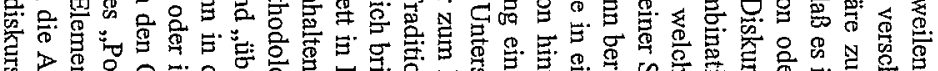

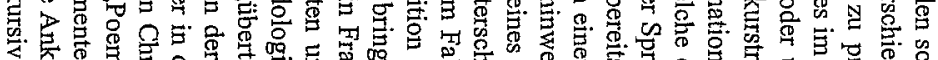

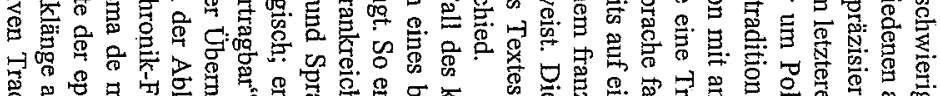

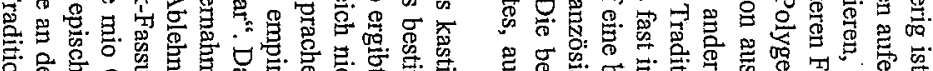

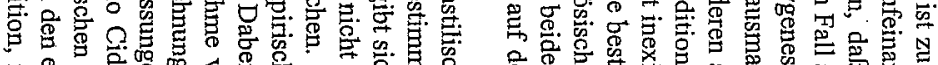

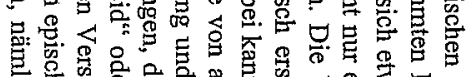

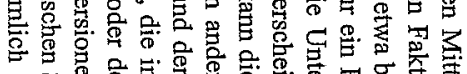

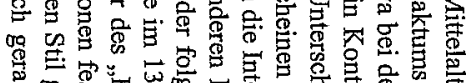

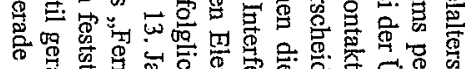

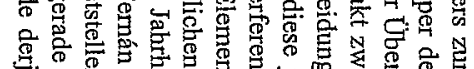

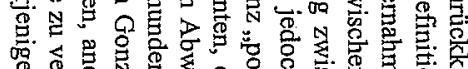

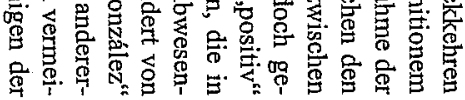
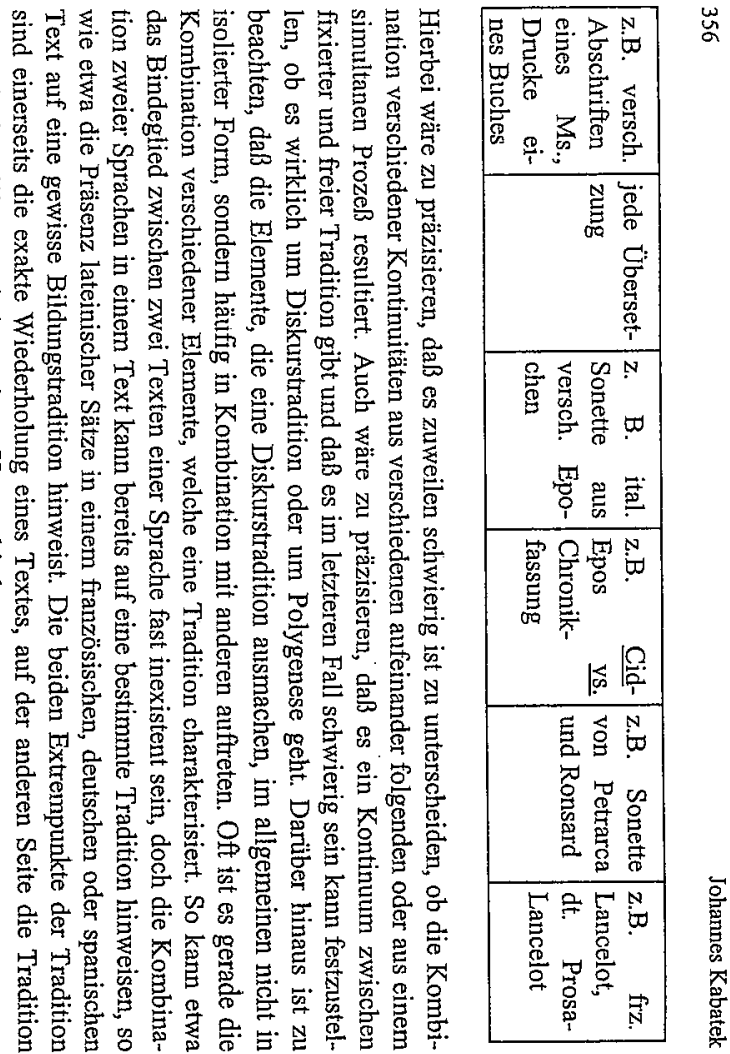

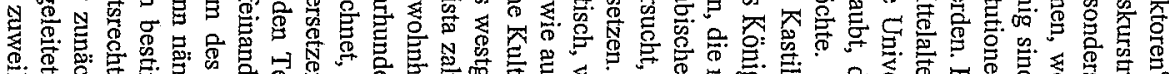

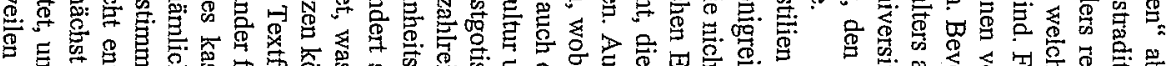

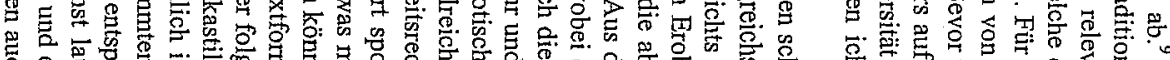

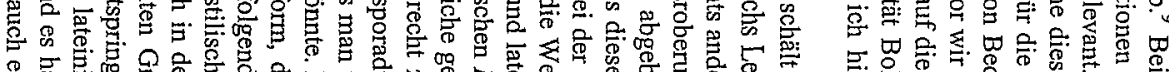

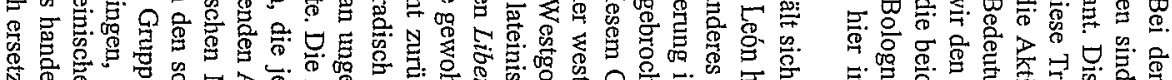

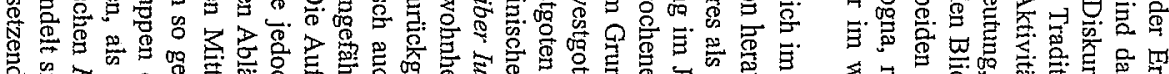

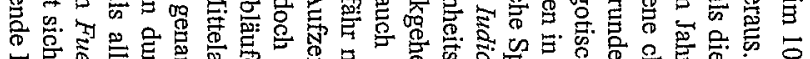

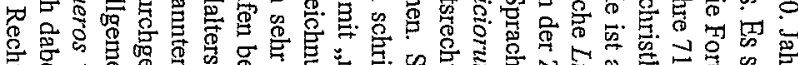

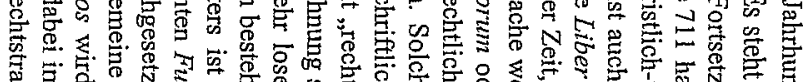

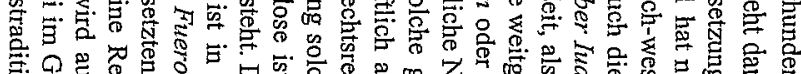

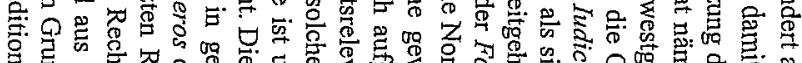

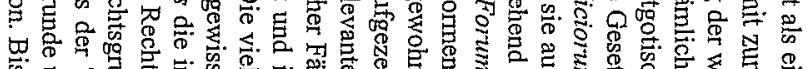

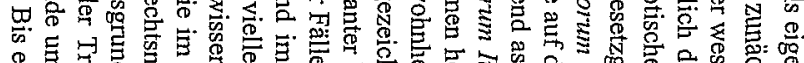

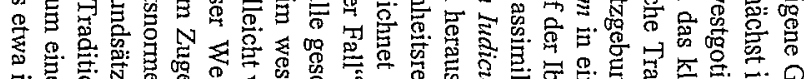

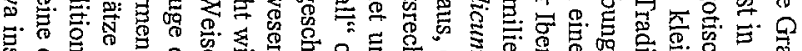
等

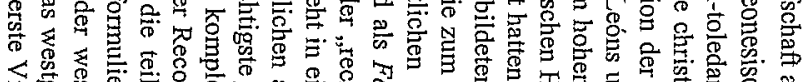

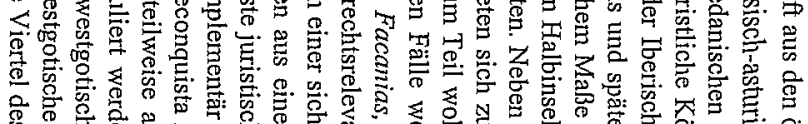

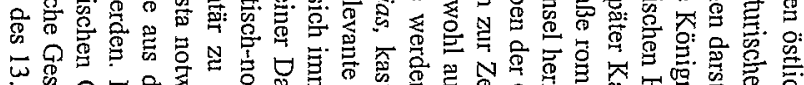

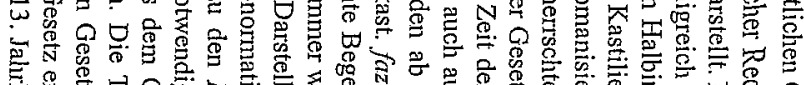

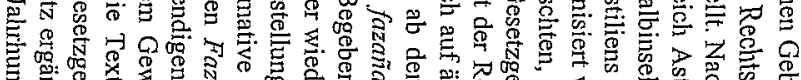

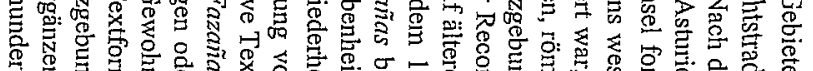

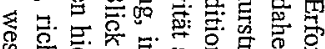

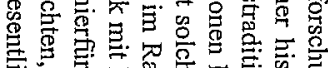

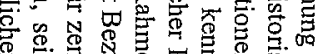

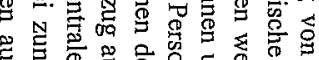

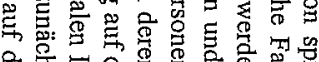

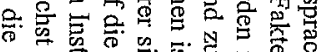

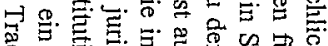

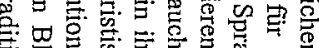

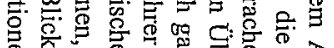

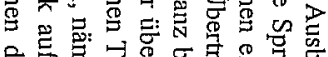

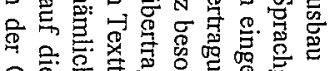
4.

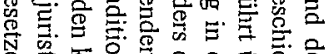

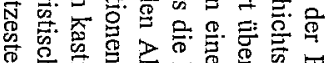

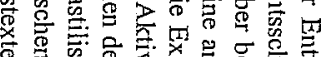

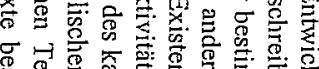

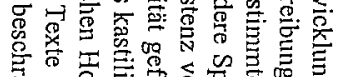

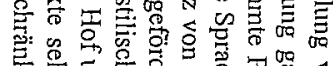

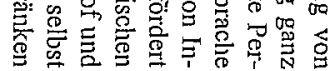



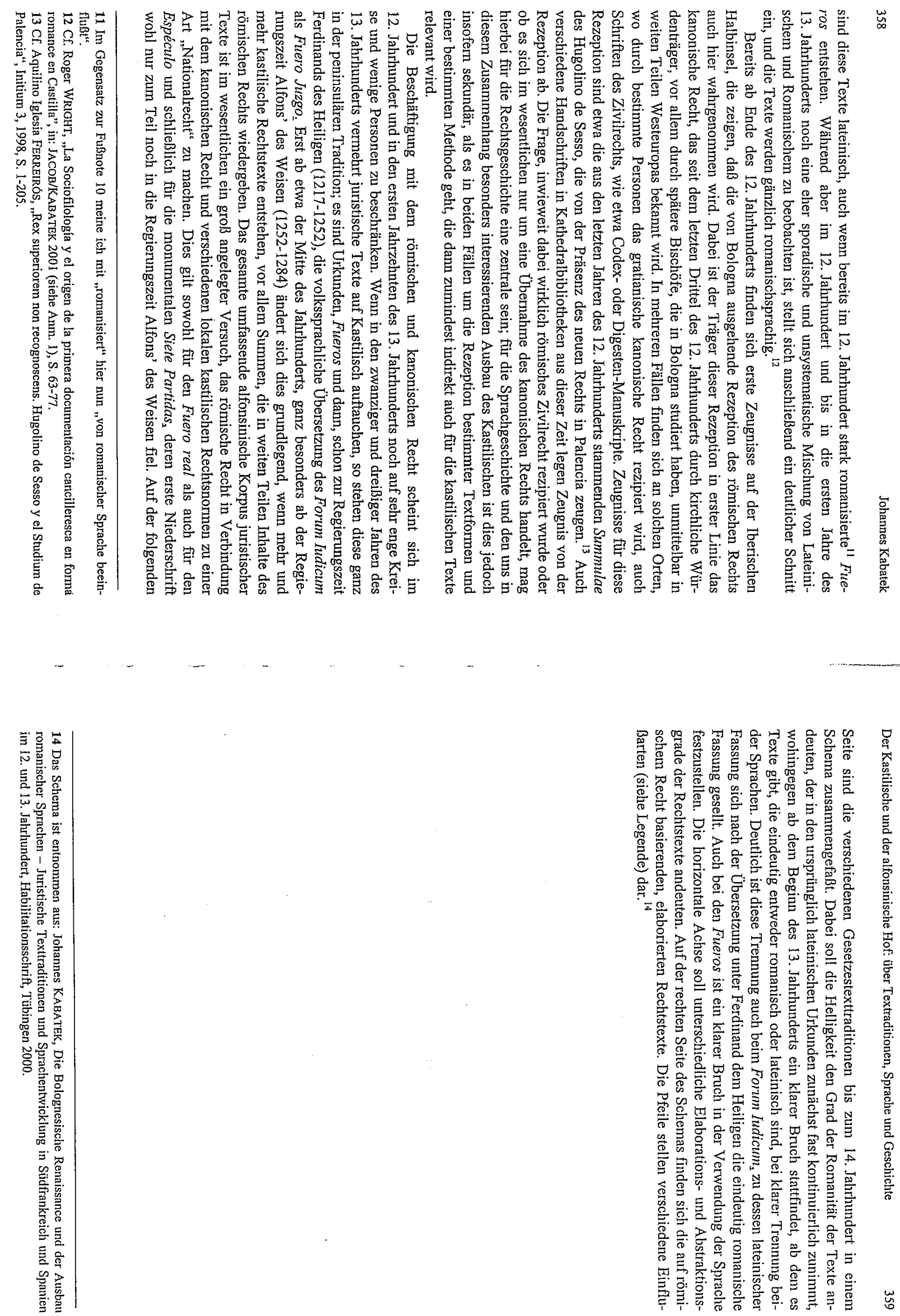


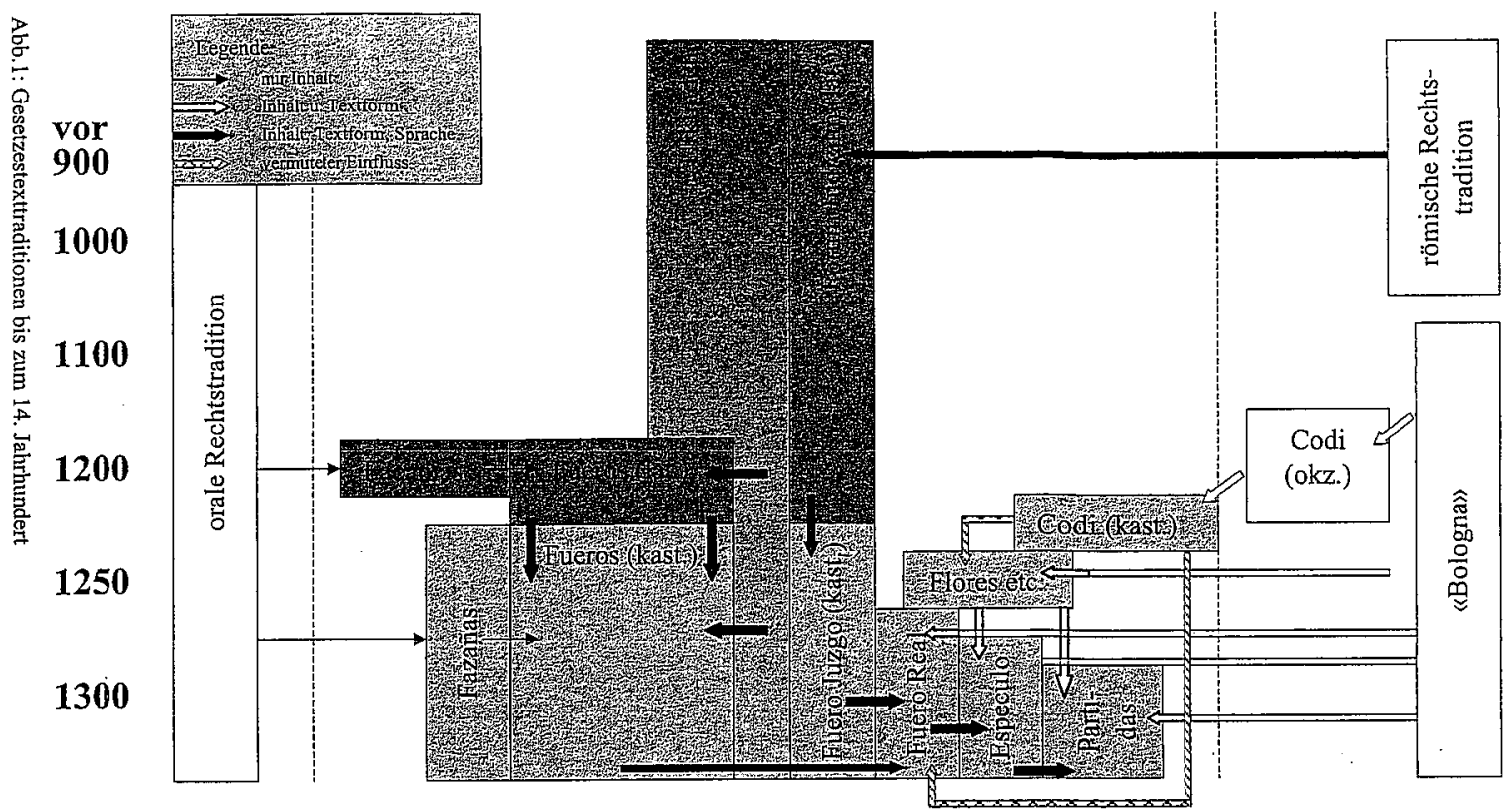

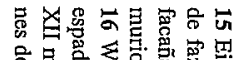

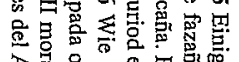

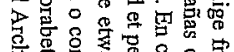

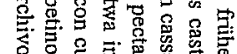
응

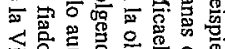

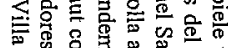

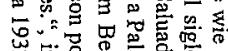

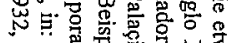

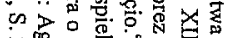
일

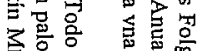
危을

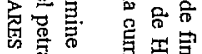

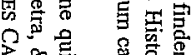

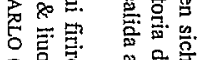

을

蛋

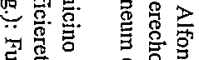

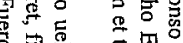

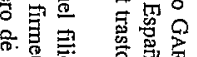

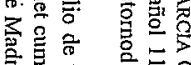

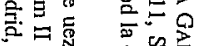

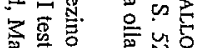

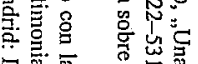

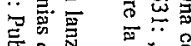

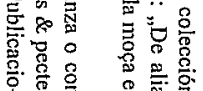

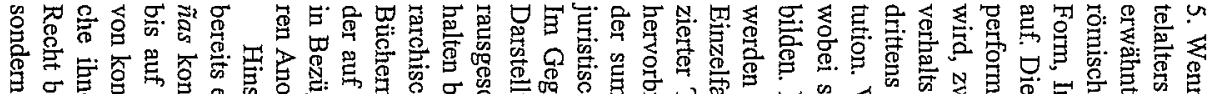

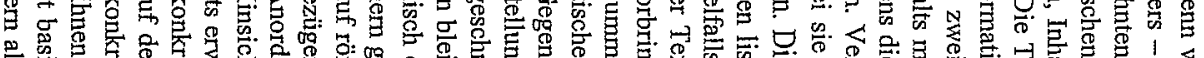

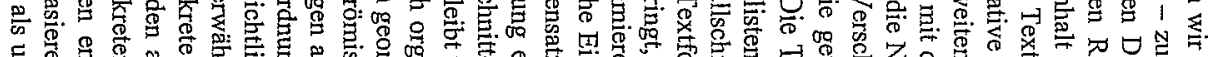

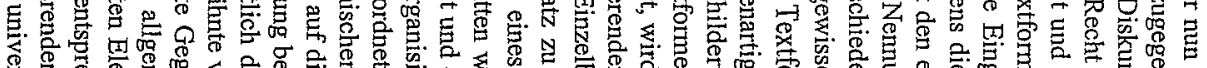

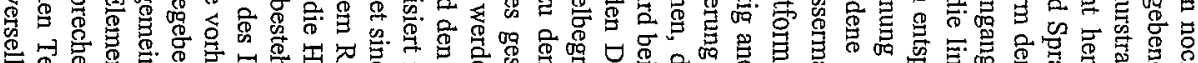

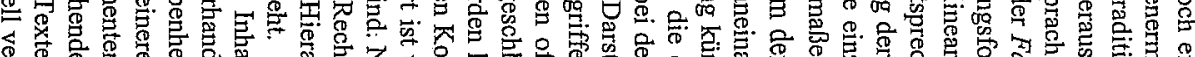

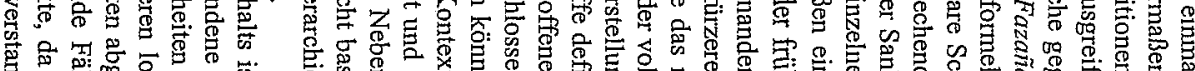

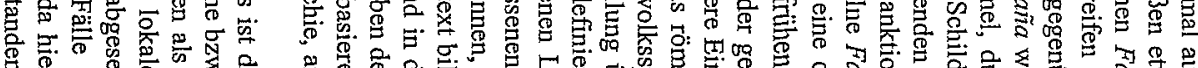

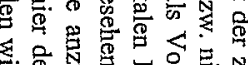

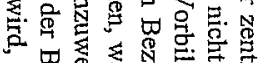

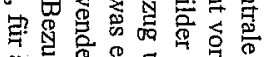

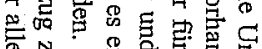

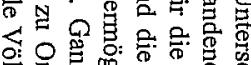

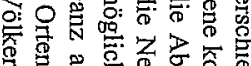

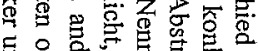

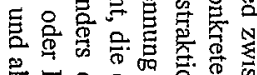

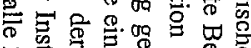
N.

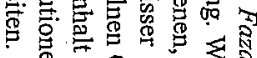

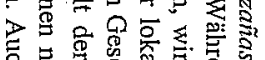

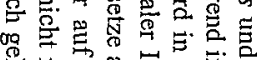

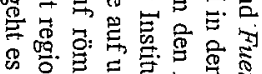

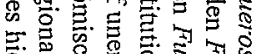
题:

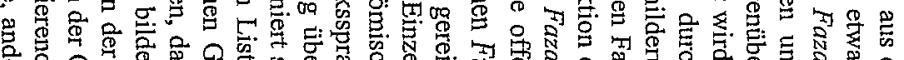

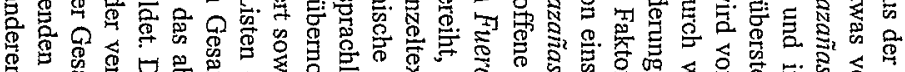

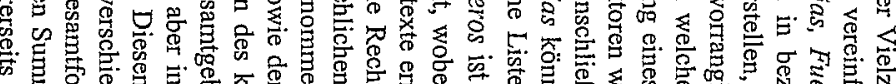

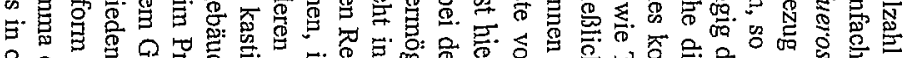

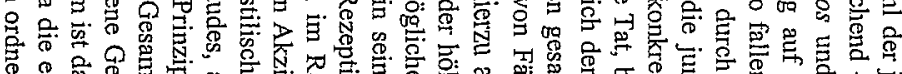

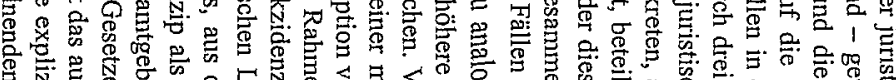

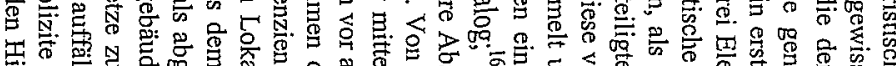

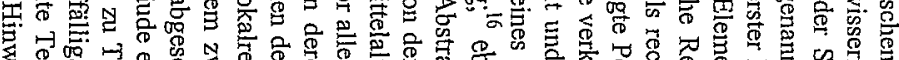

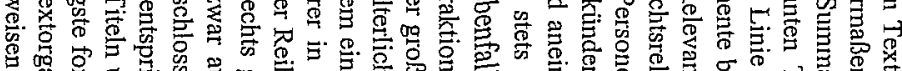

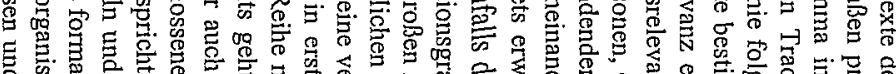

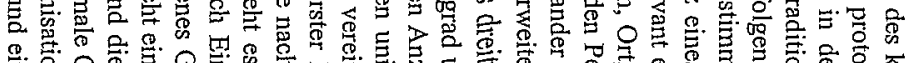

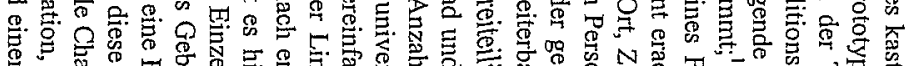

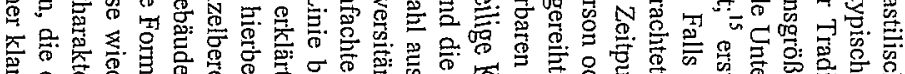

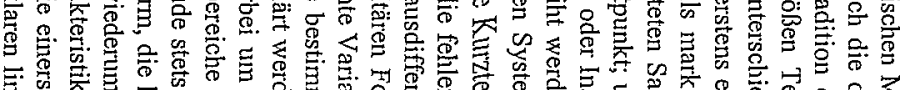

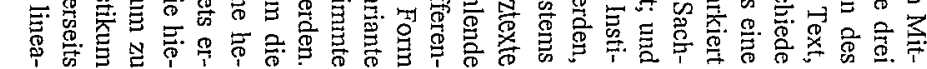




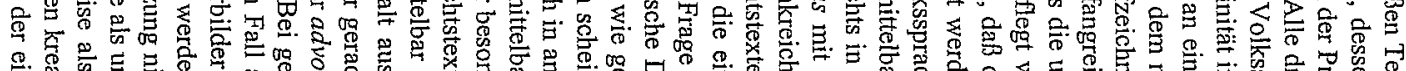

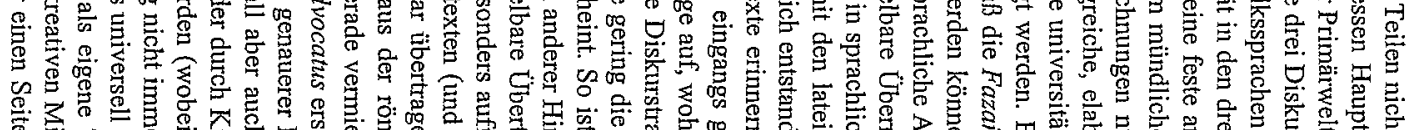

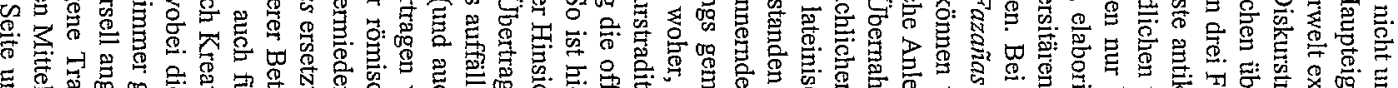

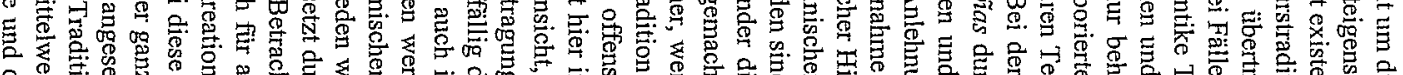

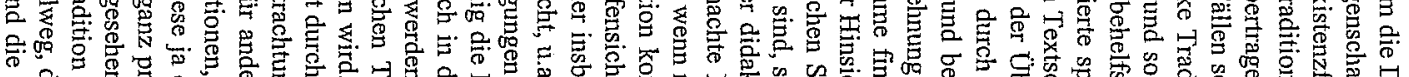

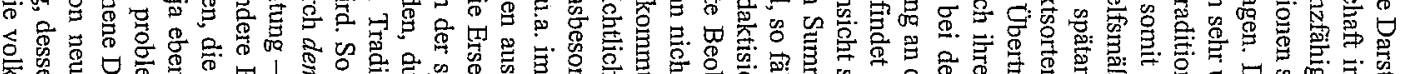

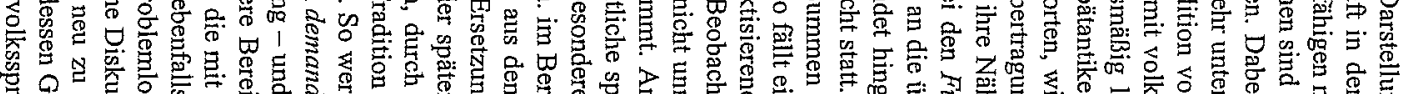

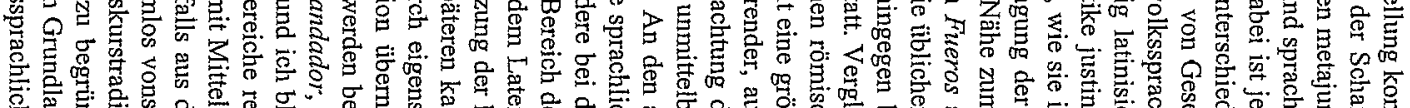

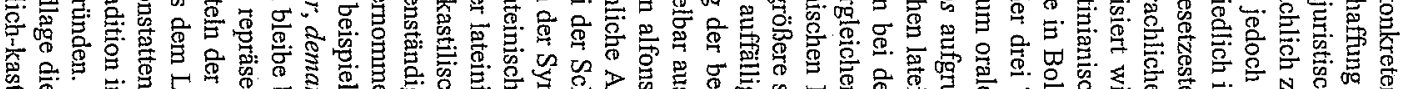

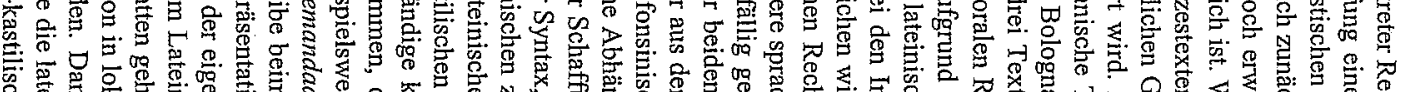

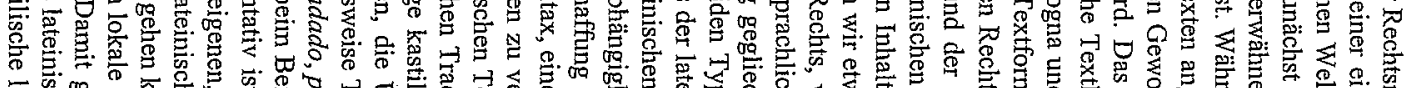

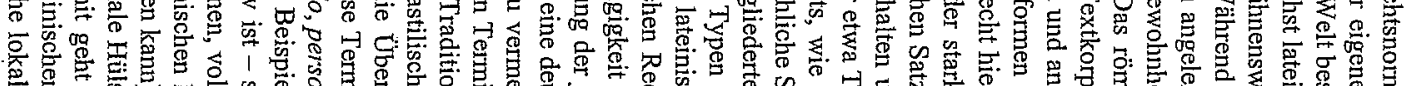

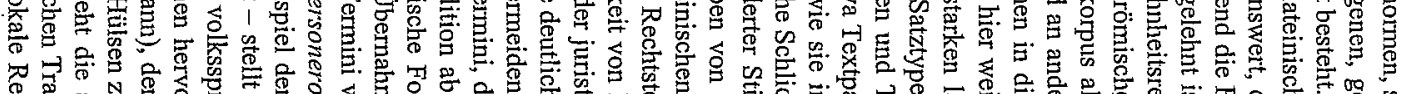

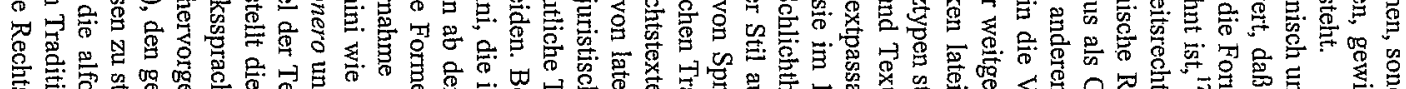

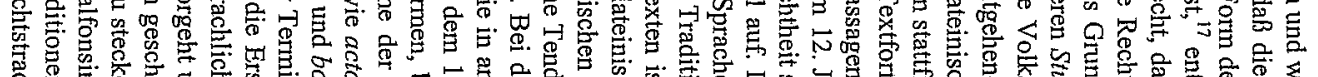

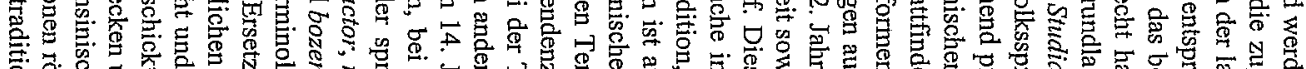

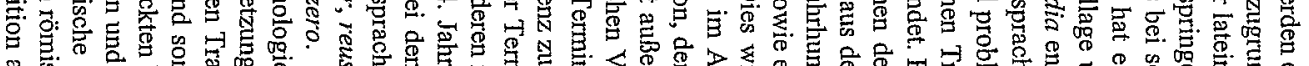

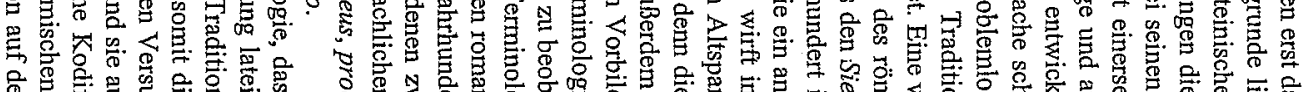

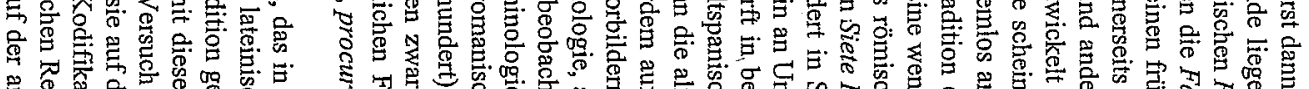

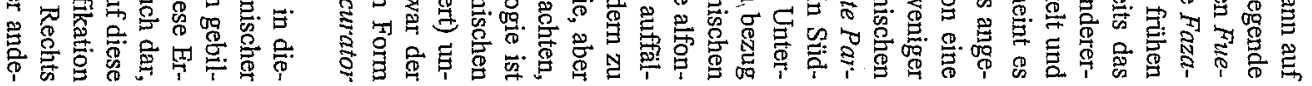

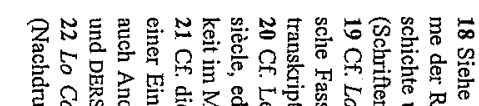

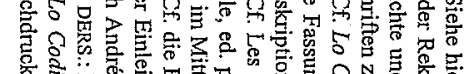

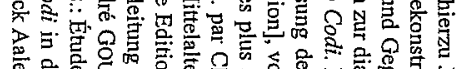

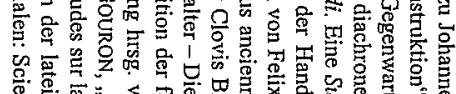
蛋

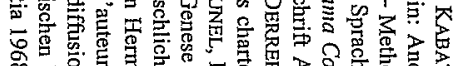

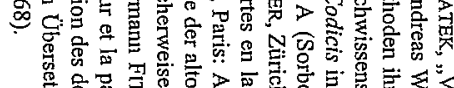

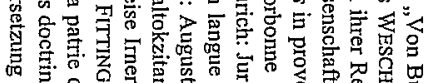
等

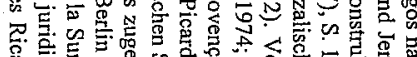

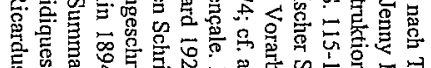
Minn

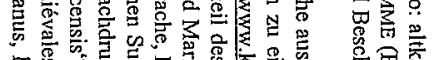

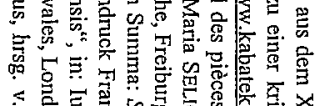

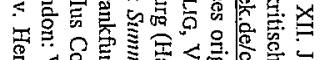

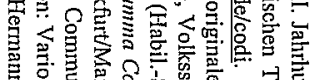

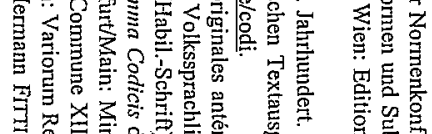

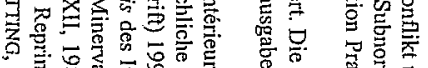

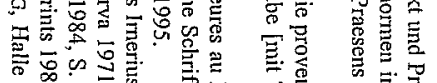

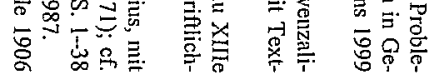

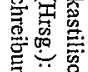
居范

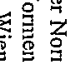

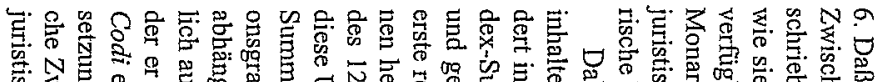

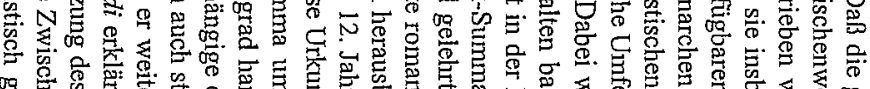

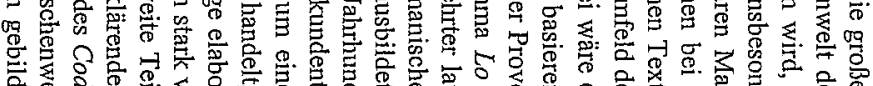

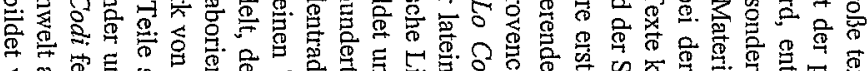

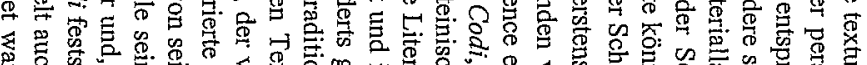

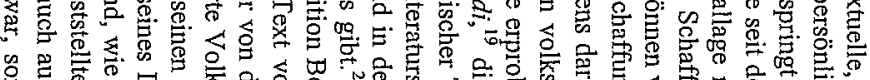

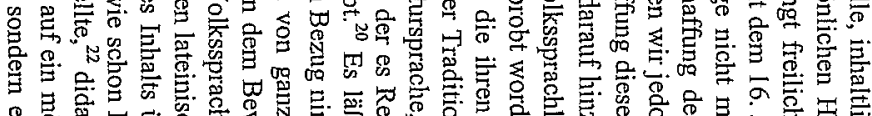

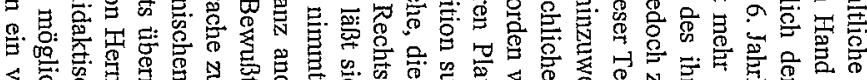

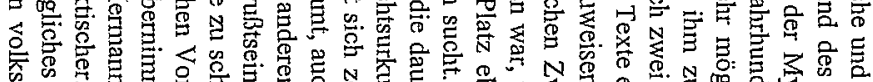

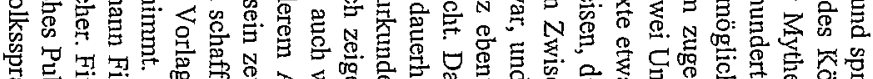

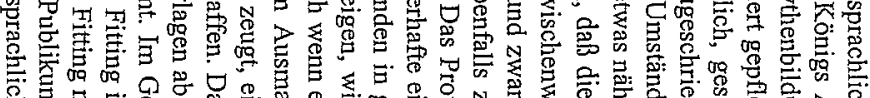

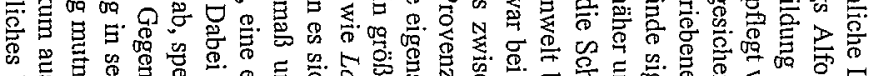

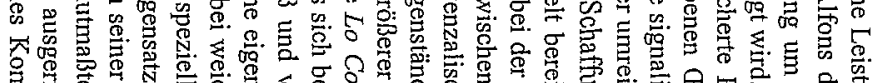

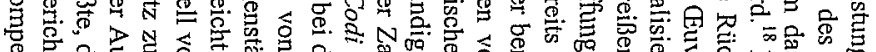

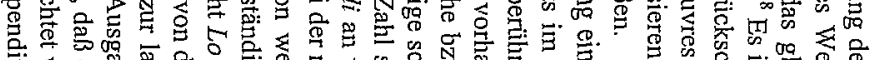

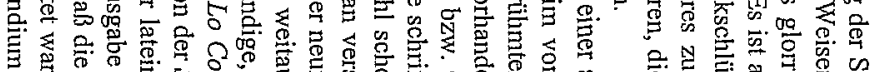

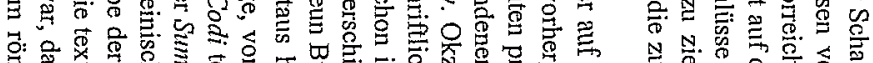

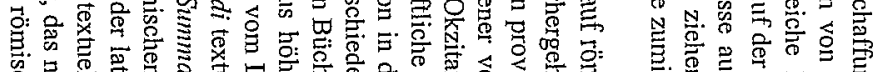

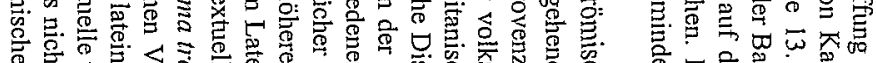

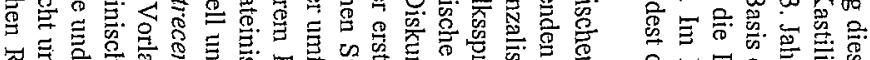

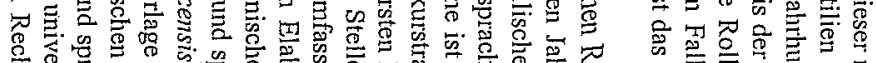

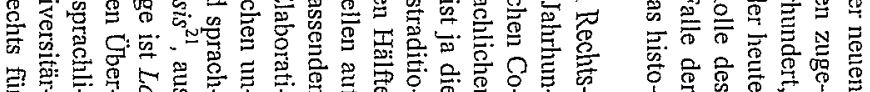




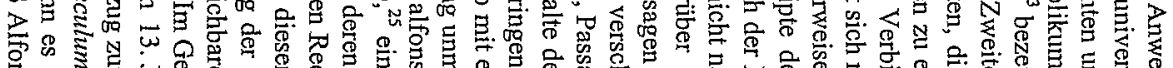

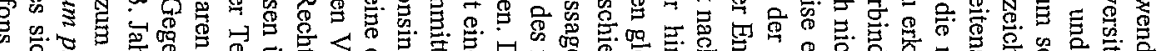

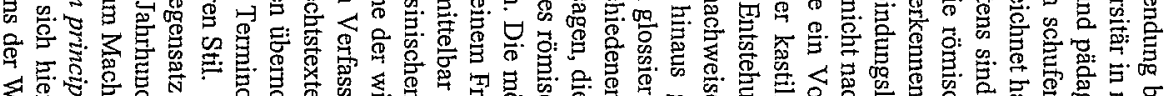

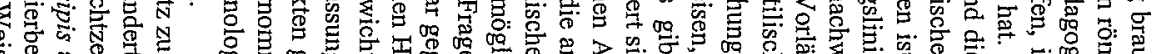

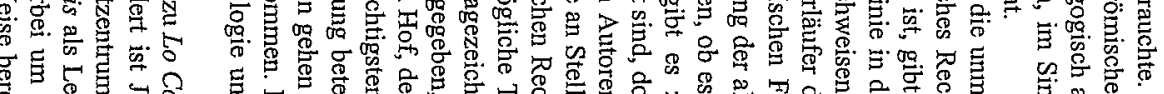

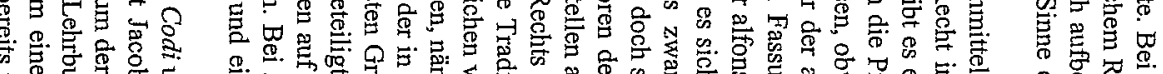

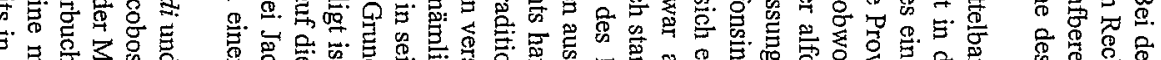
.

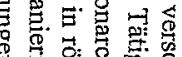

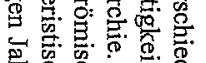

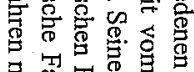

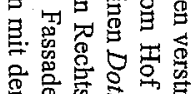

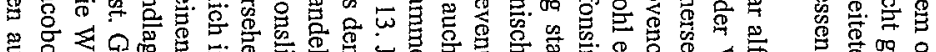

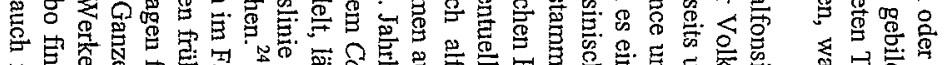

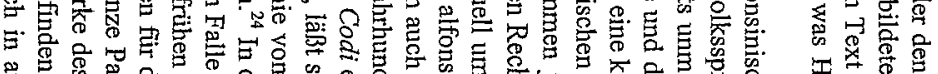

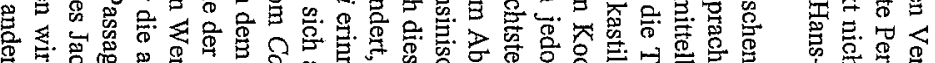

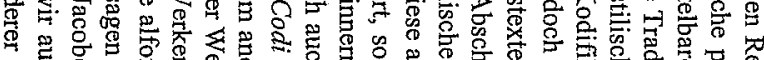

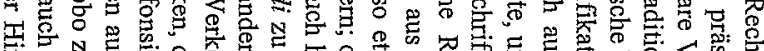

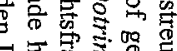

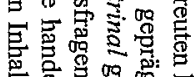

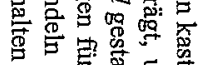

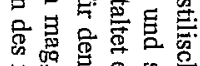

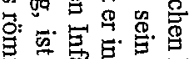

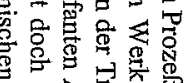

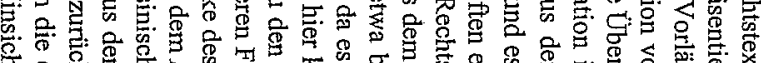

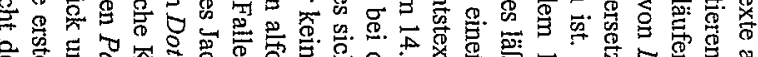

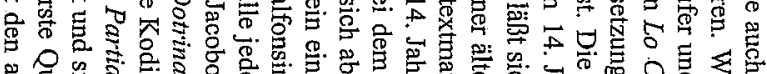

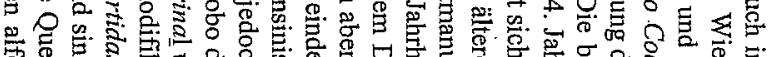

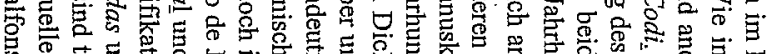

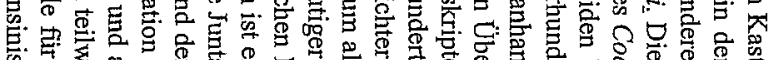

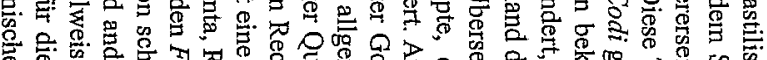

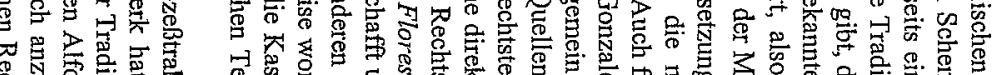

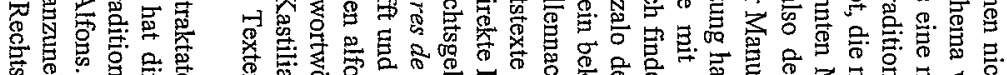
它

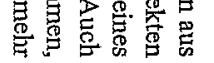

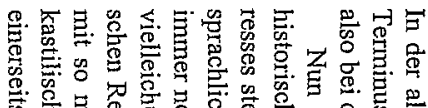

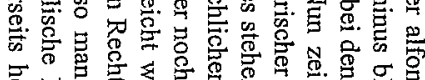

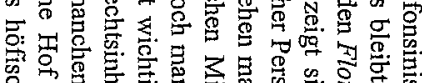

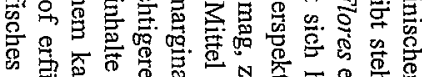

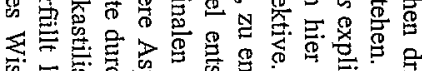

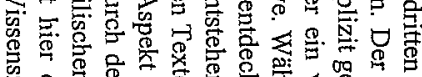

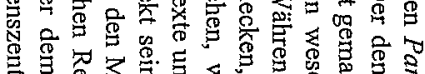

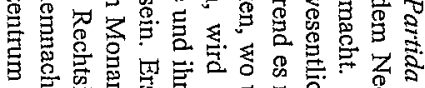

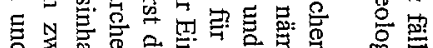
ㅇ. 응

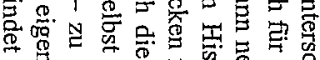

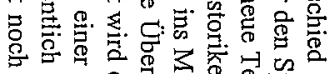

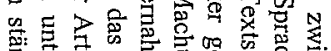

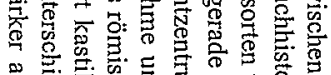

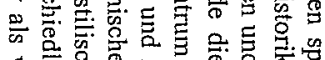

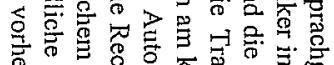

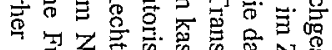
क्ञ

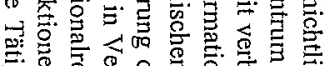

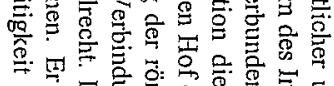

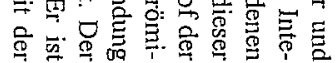

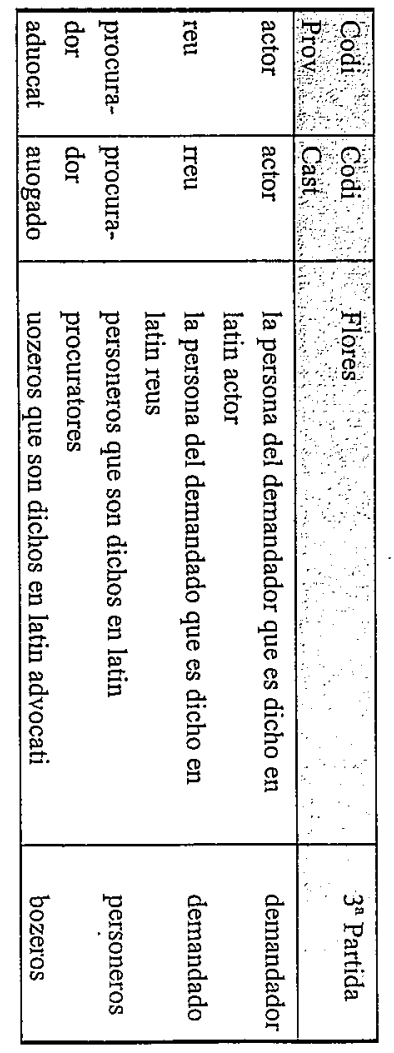

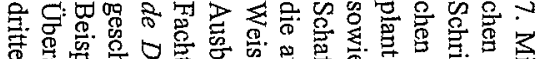

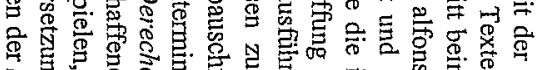

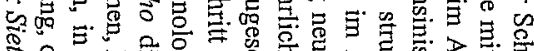

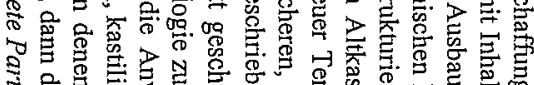

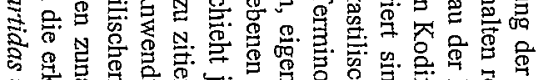

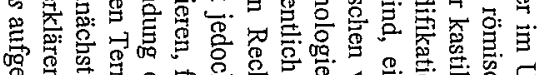

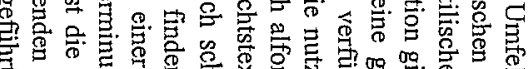

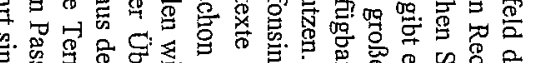

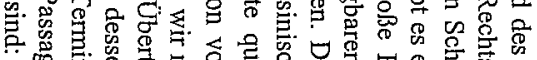

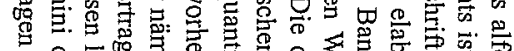

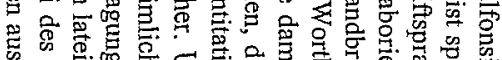

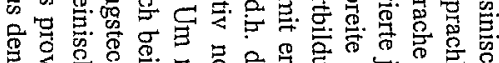

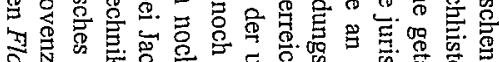

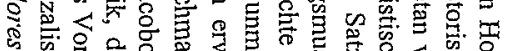

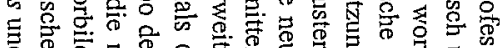

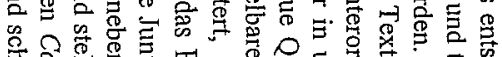

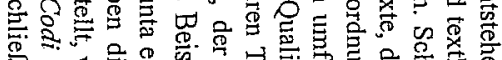

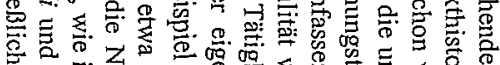

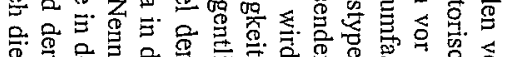

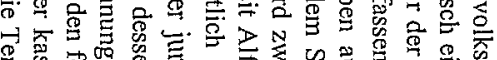

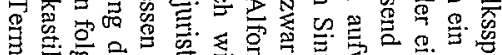

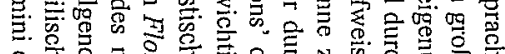

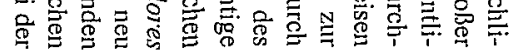

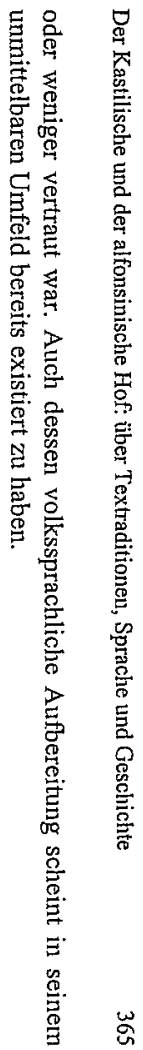

怘 


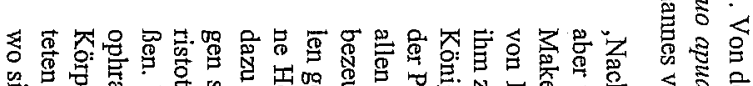

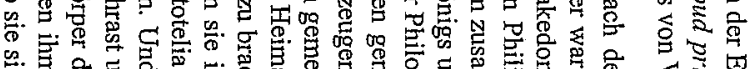

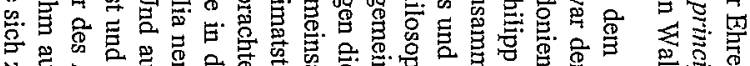

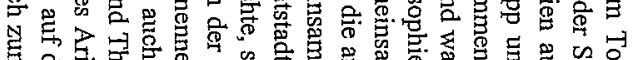

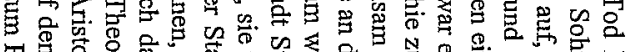

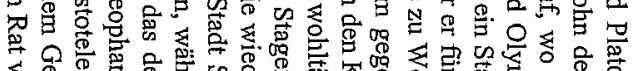
等

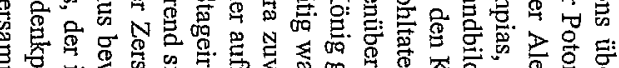

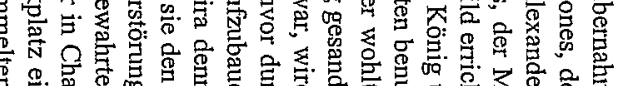

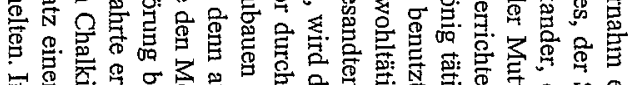

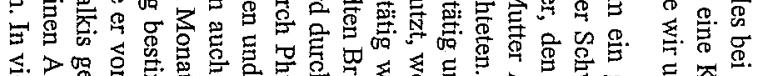

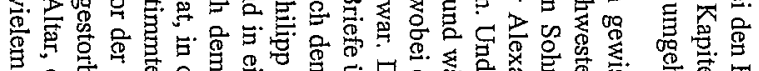

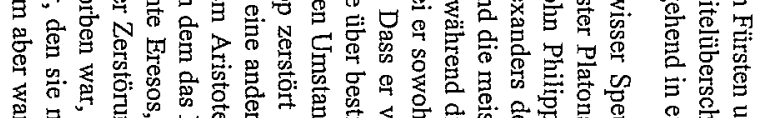

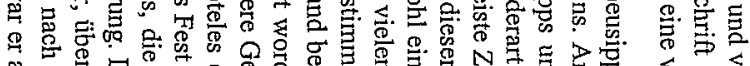

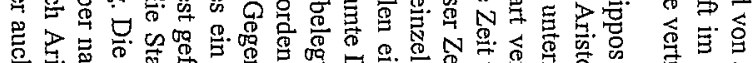

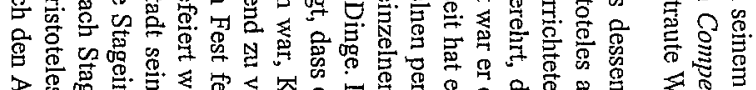

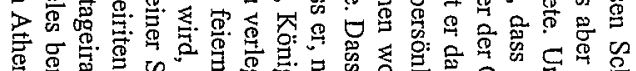

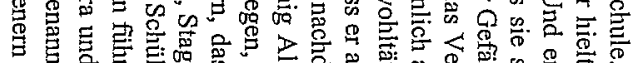

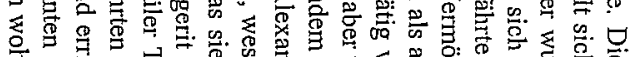

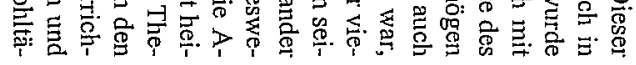

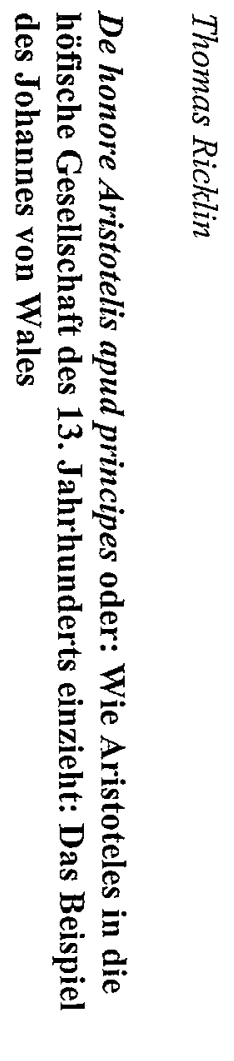

